RESULTS OF THE APPLICATION OF SEISMIC-

REFLECTION AND ELECTROMAGNETIC

TECHNIQUES FOR NEAR-SURFACE

HYDROGEOLOGIC AND ENVIRONMENTAL

INVESTIGATIONS AT FORT BRAGG,

NORTH CAROLINA

By M.T. Meyer and Jason M. Fine

U.S. GEOLOGICAL SURVEY

Water-Resources Investigations Report 97-4042

Prepared for the

Department of the Army

Fort Bragg, North Carolina

Raleigh, North Carolina 1997 


\section{U.S. DEPARTMENT OF THE INTERIOR BRUCE BABBITT, Secretary}

U.S. GEOLOGICAL SURVEY

Gordon P. Eaton, Director

The use of firm, trade, and brand names in this report is for identification purposes only and does not constitute endorsement by the U.S. Geological Survey.

For additional information write to:

Copies of this report can be purchased from:

District Chief

U.S. Geological Survey

3916 Sunset Ridge Road

Raleigh, NC 27607

\author{
U.S. Geological Survey \\ Branch of Information Services \\ Box 25286 \\ Denver Federal Center \\ Denver, CO 80225-0286
}




\section{CONTENTS}

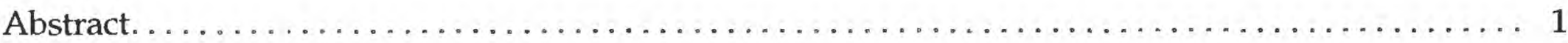

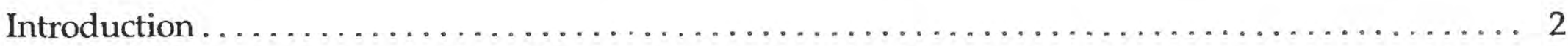

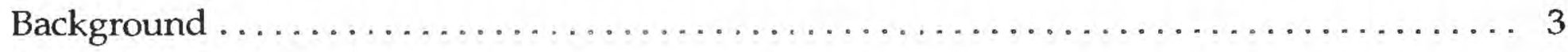

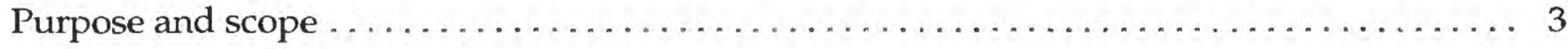

Physiographic and geologic settings . . . . . . . . . . . . . . .

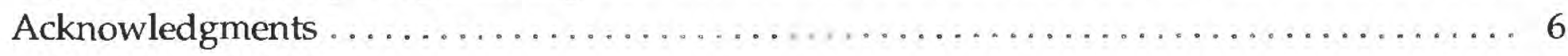

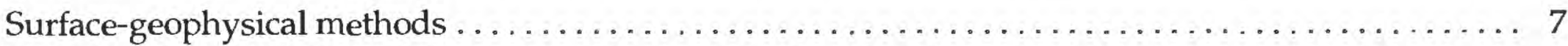

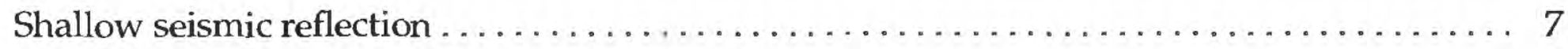

Ground-penetrating radar. . . . . . . . . . . . . . . .

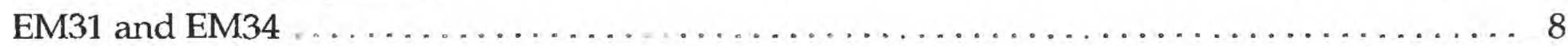

Results of geophysical investigations at selected sites $\ldots \ldots \ldots \ldots \ldots \ldots \ldots \ldots \ldots \ldots \ldots \ldots \ldots$

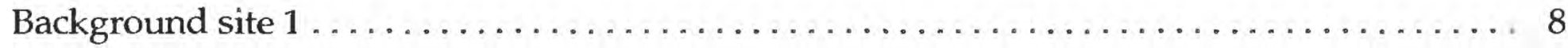

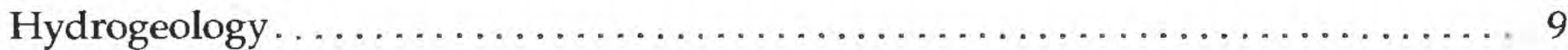

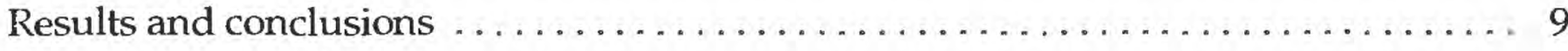

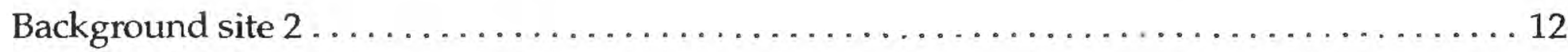

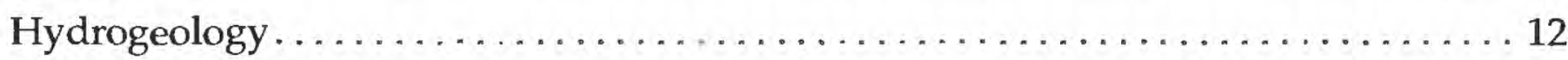

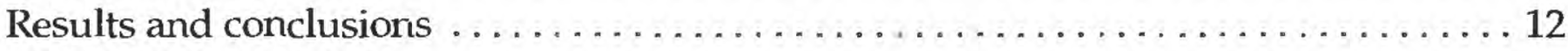

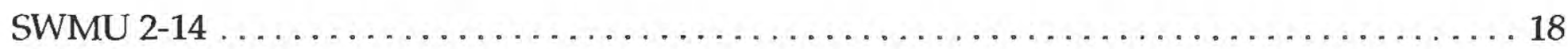

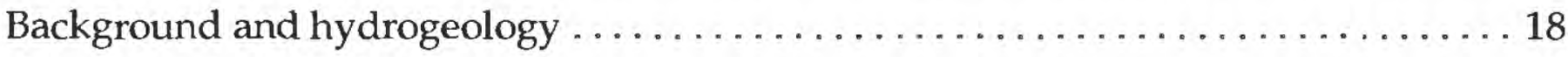

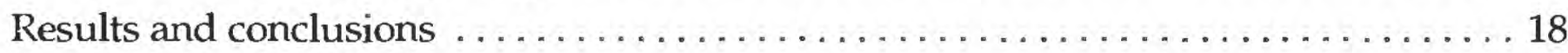

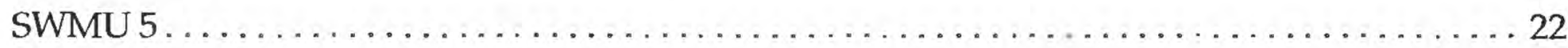

Background and hydrogeology $\ldots \ldots \ldots \ldots \ldots \ldots \ldots \ldots \ldots \ldots \ldots \ldots \ldots \ldots \ldots \ldots \ldots \ldots \ldots \ldots \ldots, 22$

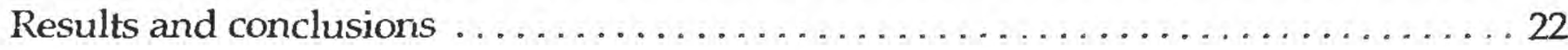

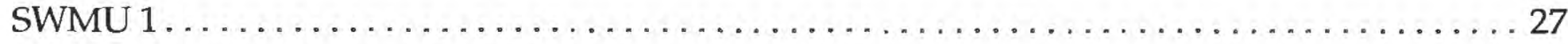

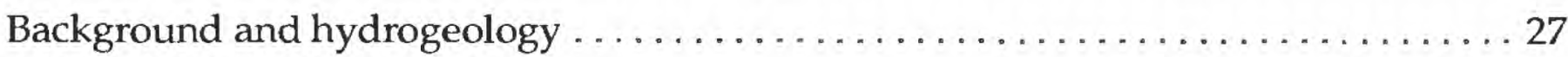

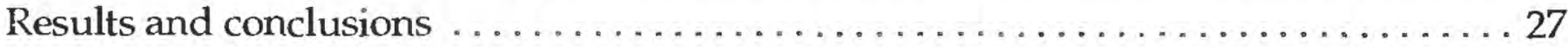

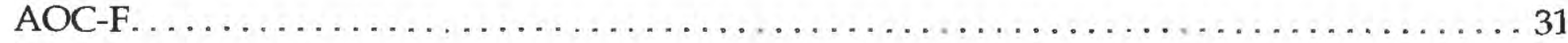

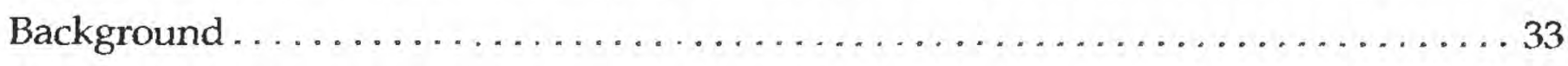

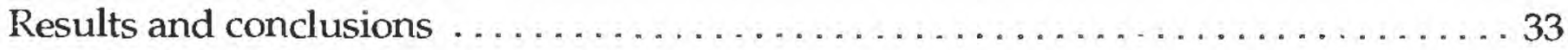

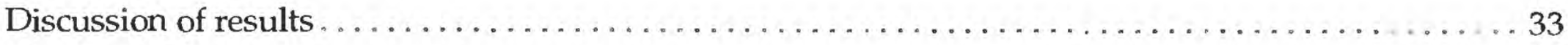

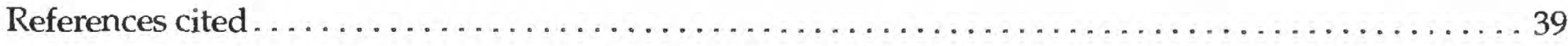




\section{FIGURES}

1. Locations of study area, generalized physiographic provinces, and study sites in relation to chief operational areas of Fort Bragg, North Carolina . . . . . . . . . . . . 2

2. Generalized relation between geologic and hydrogeologic units that underlie

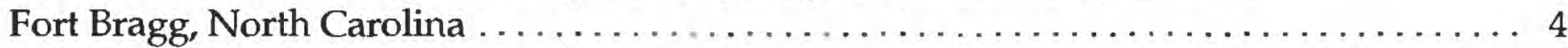

3. Surface-water drainage and geologic section A-C through Fort Bragg, North Carolina ..... 5

4. Background site 1, Fort Bragg, North Carolina............................ 10

5. Shallow seismic-reflection, processed, (A) 24-fold CDP stacked data from BGS1-1 and (B) 12-fold CDP stacked data from BGS1-2 at Fort Bragg, North Carolina . . . . . . . . 11

6. Background site 2, Fort Bragg, North Carolina........................... 13

7. Shallow seismic-reflection, processed, 24-fold CDP stacked data from BGS2-1 at Fort Bragg, North Carolina . . . . . . . . . . . . . . . . . . . . . . . 14

8. (A) Unprocessed GPR, (B) EM31-vertical dipole, and (C) EM34-conductivity data at BGS2 . 16

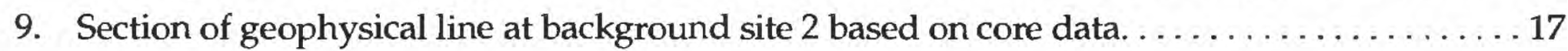

10. SWMU 2-14 and survey lines A-A', B-B', and C-C', Fort Bragg, North Carolina . . . . . . . . 19

11. (A) Unprocessed GPR and (B) EM31 vertical-dipole data at SWMU 2-14 along

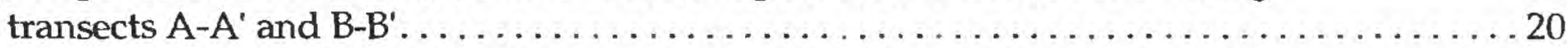

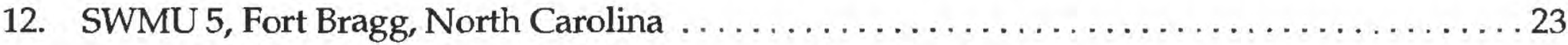

13. Gamma-ray logs and lithology for selected wells at SWMU $5 \ldots \ldots \ldots \ldots \ldots \ldots \ldots \ldots \ldots \ldots \ldots \ldots$

14. (A) EM31-conductivity and (B) inphase data plots imposed at SWMU 5, Fort Bragg,

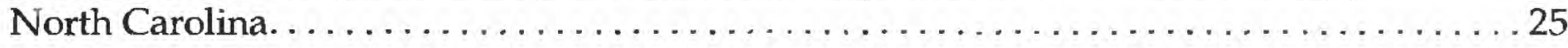

15. Conductivity values collected in 1991 using the EM34 configured for a theoretical exploration depth of 50 feet. . . . . . . . . . . . . . . . . . . . . 26

16. SWMU 1, Fort Bragg, North Carolina, and geologic section A-A' . . . . . . . . . . . 28

17. Borehole geophysical logs for selected wells at SWMU 1 and reference log from SWMU $3 \ldots 29$

18. SWMU 1 with (A) EM31 EM-conductivity and (B) inphase readings imposed. . . . . . . . 30

19. Unprocessed GPR data from selected survey lines at SWMU 1, Fort Bragg, North Carolina. . . . . . . . . . . . . . . . . . . . . . . . . . . . . . . . . . . . . 32

20. GPR and EM31 lines at AOC-F, Fort Bragg, North Carolina $\ldots \ldots \ldots \ldots \ldots \ldots \ldots \ldots \ldots \ldots$

21. Location of AOC-F with (A) EM31-conductivity and (B) inphase plots imposed......... 35

22. Unprocessed GPR data at AOC-F, collected using $500-\mathrm{MHz}$ antenna. . . . . . . . . 36

\section{TABLES}

1. Usefulness of GPR, EM31, and EM34 techniques for environmental studies at

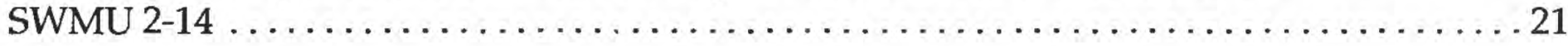

2. Usefulness of EM31 and EM34 techniques for environmental studies at SWMU $5 \ldots \ldots \ldots 27$

3. Usefulness of EM31 and GPR techniques for hydrogeologic and environmental

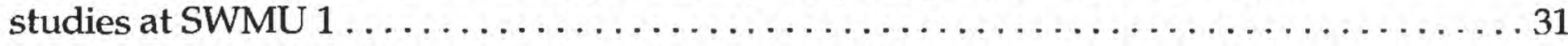

4. Summary of conclusions for the usefulness of geophysical techniques for mapping the shallow subsurface geology at Fort Bragg, North Carolina . . . . . . . . . . . . 37

5. Summary of conclusions for the usefulness of geophysical techniques for environmental studies at Fort Bragg, North Carolina 


\title{
RESULTS OF THE APPLICATION OF SEISMIC-REFLECTION AND ELECTROMAGNETIC TECHNIQUES FOR NEAR-SURFACE HYDROGEOLOGIC AND ENVIRONMENTAL INVESTIGATIONS AT FORT BRAGG, NORTH CAROLINA
}

\author{
by M.T. Meyer and Jason M. Fine
}

\section{ABSTRACT}

As part of the U.S. Geological Survey's Resource Conservation and Recovery Act, Facilities Investigations at Fort Bragg, North Carolina, selected geophysical techniques were evaluated for their usefulness as assessment tools for determining subsurface geology, delineating the areal extent of potentially contaminated landfill sites, and locating buried objects and debris of potential environmental concern. Two shallow seismic-reflection techniques (compression and shear wave) and two electromagnetic techniques (ground-penetrating radar and terrain conductivity) were evaluated at several sites at the U.S. Army Base. The electromagnetic techniques also were tested for tolerance to cultural noise, such as nearby fences, vehicles, and power lines. For the terrain conductivity tests, two instruments were used --the EM31 and EM34, which have variable depths of exploration.

The shallowest reflection event was 70 feet below land surface observed in common-depth point, stacked compression-wave data from 24and 12-fold shallow-seismic-reflection surveys. Several reflection events consistent with clay-sand interfaces between 70 and 120 feet below land surface, along with the basement-saprolite surfaces, were imaged in the 24-fold, commondepth-point stacked data. 12-fold, common-depthpoint stacked data set contained considerably more noise than the 24-fold, common-depth-point data, due to reduced shot-to-receiver redundancy. Coherent stacked reflection events were not observed in the 24-fold, common-depth-point stacked shear-wave data because of the partial decoupling of the shear-wave generator from the ground.

At one site, ground-penetrating radar effectively delineated a shallow, 2- to 5-foot thick sand unit bounded by thin (less than 1 foot) clay layers. The radar signal was completely attenuated where the overlying and underlying clay units thickened and the sand unit thinned. The penetration depth of the radar signal was less than 10 feet below land surface. A slight increase in electromagnetic conductivity across shallow sampling EM31 and EM34 profiles provided corroborative evidence of the shallow, thickening clay units. Plots of raw EM31 and EM34 data provided no direct interpretable information to delineate sand and clay units in the shallow subsurface. At two sites, the ground-penetrating radar effectively delineated the lateral continuity of surficial sand units 5 to 25 feet in thickness and the tops of their underlying clay units. The effective exploration depth of the groundpenetrating radar was limited by the proximity of clay units to the subsurface and their thickness.

The ground-penetrating radar delineated the areal extent and depth of cover at a previously unrecognized extension of a trench-like landfill underlying a vehicle salvage yard. Attenuation of the radar signal beneath the landfill cover and the adjacent subsurface clays made these two mediums indistinguishable by ground-penetrating radar; however, EM31 data indicated that the electrical conductivity of the landfill was higher than the subsurface material adjacent to the landfill.

The EM31 and EM34 conductivity surveys defined the areal extent of a landfill whose 
boundaries were inaccurately mapped, and also identified the locations of an old dumpsite and waste incinerator site at another landfill. A followup ground-penetrating radar survey of the abandoned dumpsite showed incongruities in some of the shallow radar reflections interpreted as buried refuse dispersed throughout the landfill. The ground-penetrating radar and EM31 effectively delineated a shallow buried fuel-oil tank.

Of the three electromagnetic instruments, the ground-penetrating radar with the shielded 100-megahertz antenna was the least affected by cultural noise followed, in order, by the EM31 and EM34. The combination of terrain-conductivity and ground-penetrating radar for the site assessment of landfill provided a powerful means to identify the areal extent of landfill, potential areas of concern within landfill, and information on the shallow subsurface geology.

\section{INTRODUCTION}

The U.S. Army Base at Fort Bragg, North Carolina (fig. 1), contains solid-waste management units (SWMU's) where hazardous materials may have been stored or disposed or both. The U.S. Geological Survey (USGS) is conducting Resource Conservation and Recovery Act (RCRA) Facility Investigations (RFI) at these sites as required by the U.S. Environmental Protection Agency (U.S. EPA) (U.S. Environmental Protection Agency, 1976).

The shallow subsurface hydrology at Fort Bragg is influenced by interbedded sands, with varying amounts of silt and clay 10 to 15 feet (ft) thick and clay from less than $1 \mathrm{ft}$ to more than $10 \mathrm{ft}$ thick. Because subsurface geology generally plays an important role in contaminant transport and shallow aquifers are most at risk to contaminant transport, delineation of the shallow subsurface geology in the vicinity of the SWMU's is important. In addition, it is important to identify the areal extent of the SWMU's and areas within the SWMU's that may contain sources of contamination.

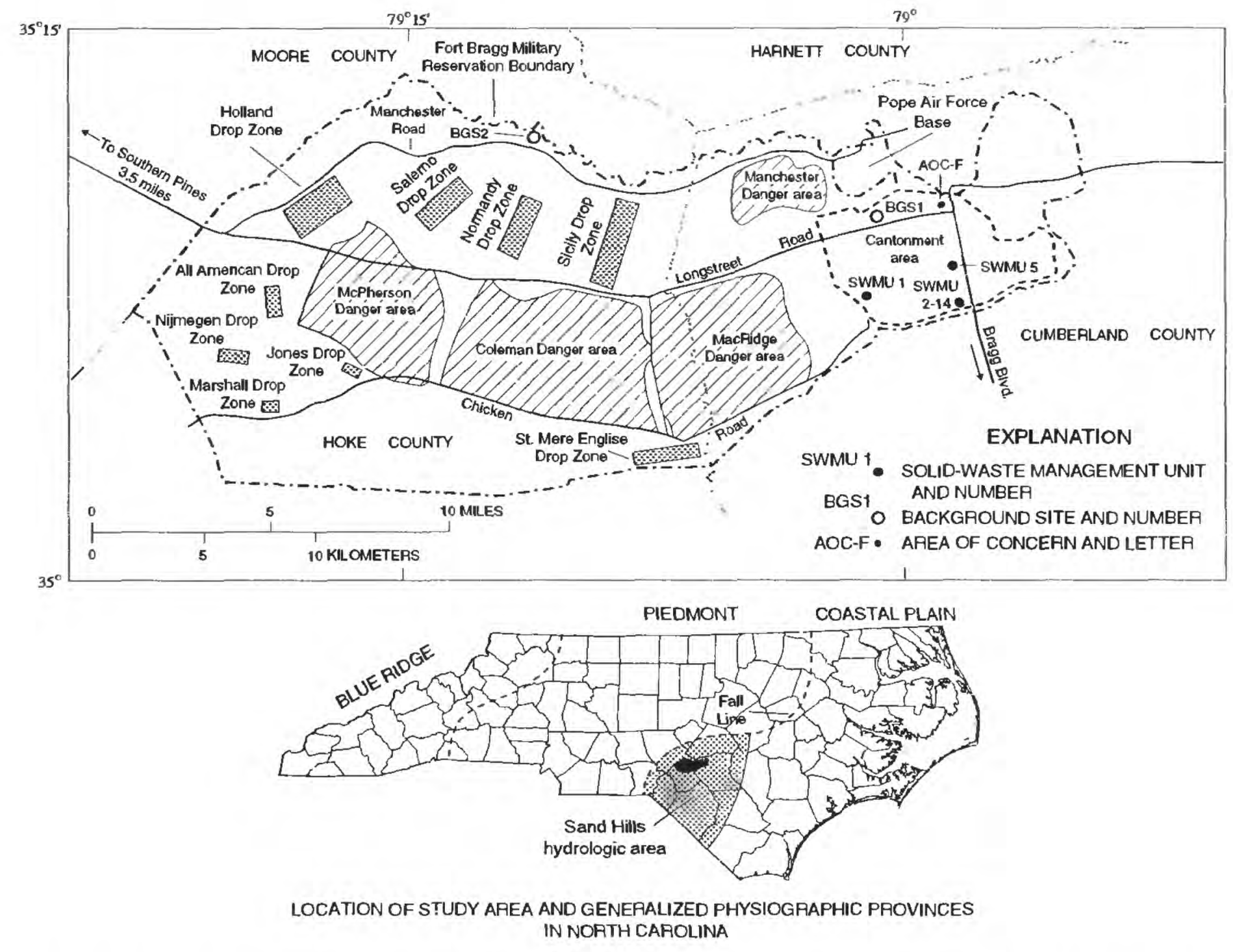

Figure 1. Locations of study area, generalized physiographic provinces, and study sites in relation to chief operational areas of Fort Bragg, North Carolina. 
Surface geophysical methods can provide information about subsurface geology and identify areas and objects of potential environmental concern. Data provided by geophysical surveys also can be used in the selection of appropriate locations for soil borings, monitoring wells, sample collection, and may provide a means to better correlate shallow subsurface geology between stratigraphic boreholes.

Shallow seismic-reflection techniques have been used for a variety of geologic and hydrogeologic applications (for example, Miller and others, 1986; Birkelo and others, 1987; Miller and others, 1989; Steeples and Miller, 1990; Miller, 1992; Miller and others, 1994; Boyce and others, 1995; Klimentos, 1995; Miller, Anderson, and others, 1995; Miller and others, in press). Also, electromagnetic surveys using groundpenetrating radar (GPR) and terrain-conductivity techniques have been evaluated and used to delineate shallow subsurface geology, contaminant plumes, and objects of environmental concern (for example, Davis and others, 1984; Brus and others, 1992: Winn, 1992; Drane, 1993; Perry and others, 1993; Brennan, 1994; Perry, 1994; Salama and others, 1994; Soldal and others; 1994; Benson, 1995; Daniels and others, 1995; Dominic and others, 1995; Mellett, 1995; Olsen and Andreasen, 1995; Smith and Jol, 1995). However, in areas underlain by unconsolidated, interbedded sands and clays such as those that underlie Fort Bragg, the usefulness of surfacegeophysical surveys has not been well studied.

Surface geophysical surveys can be conducted relatively quickly, generally are not intrusive, and can be used as site-assessment tools for hydrogeologic and environmental studies. Lieblich and others (1992) demonstrated that multiple surface-geophysical techniques should be used to ensure proper interpretation of data. However, the usefulness of these methods is highly site specific and must be evaluated on a site-by-site basis. Selected techniques were tested at a variety of sites at Fort Bragg, North Carolina, to evaluate their usefulness in hydrogeologic and environmental investigations at the Base.

\section{Background}

In 1994, the USGS conducted an investigation in cooperation with the U.S. Army at Fort Bragg, North Carolina, to evaluate selected surface geophysical methods to determine their usefulness in hydrogeologic and environmental studies at the Base. Fort Bragg was established in 1918 as the major staging area for the XVII Airborne Corps and covers about 203 square miles $\left(\mathrm{mi}^{2}\right)$ in the Sand Hills hydrologic area of southeastern North Carolina (fig. 1). At this time, approximately $185 \mathrm{mi}^{2}$ are designated for field maneuvers, exercises, parachute drop zones, firing ranges, and impact danger areas where a variety of explosives are handled. The other $18 \mathrm{mi}^{2}$ compose an area known as the cantonment area where military maintenance and production facilities, operation and training facilities, community facilities, and family and troop housing are located (fig. 1).

The cantonment area is located in the easternmost section of the Base and contains 32 SWMU's. Most of these SWMU's have been grouped into Operable Units (OU's) for RFI studies conducted by the USGS. Potential environmental hazards which are most commonly found within these OU's include abandoned landfills, underground storage tanks, oil-water separators, and vehicle repair and storage yards. Although surface geophysical surveys have been conducted on some of the SWMU's as part of the RFI investigations, an evaluation of the different geophysical survey methods and their use in ongoing and future studies at Fort Bragg has not been done previously.

\section{Purpose and Scope}

This report summarizes the application and usefulness of shallow seismic-reflection and electromagnetic techniques in a variety of geologic and environmental settings commonly encountered at Fort Bragg, North Carolina, particularly in the cantonment area where most of the potentially contaminated sites are located. Field work for this investigation was conducted between March 1994 and August 1996.

For this investigation, two shallow seismicreflection techniques (compression (P) and shear (S) wave) and two electromagnetic techniques (groundpenetrating radar and terrain conductivity) were tested at two sites used for background sampling for the RFI's at the Base. Because of their expertise in the development and application of shallow, seismic-reflection techniques, the Kansas Geological Survey (KGS) was contracted to conduct shallow seismic-reflection studies at these two background sites (BGS). Two electromagnetic techniques, GPR and terrain-conductivity, also were evaluated for use in delineating the areal extent and depth of landfills at three SWMU's and a buried fuel tank at a location identified as an area of concern (AOC) at Fort Bragg. Terrain conductivity tests were conducted with the Geonics EM31 and EM34. 


\section{Physiographic and Geologic Settings}

Fort Bragg is located in the Coastal Plain Province of North Carolina near the western boundary and in the Sand Hills hydrologic area (fig. 1). The Fall Line separates the Piedmont Province to the west from the Coastal Plain Province, which is defined by a sedimentary wedge that dips towards the southeast and thickens from $0 \mathrm{ft}$ at the Fall Line to as much as $10,000 \mathrm{ft}$ at the Atlantic Ocean (Brown and others, 1972; Winner and Coble, 1996).

The most variable and highest land-surface elevations in the Coastal Plain occur in the Sand Hills hydrologic area. The topography of Fort Bragg is characterized by shallow to steep ridges, with the highest ridges occurring in the western and central parts of the Base. The altitude of the land surface at the Base ranges from approximately $150 \mathrm{ft}$ in the northeast to $550 \mathrm{ft}$ at the western edge of Fort Bragg.

The basement rocks that underlie Coastal Plain sediments in North Carolina are composed mostly of metasedimentary, metavolcanic, and igneous rocks (Conley, 1962; fig. 2). Data from deep boreholes shown in figure 3 indicate that much of the basement rock underlying Fort Bragg is composed of chlorite schist
(S.L. Harden, U.S. Geological Survey, written commun., 1994). The altitude of the basement rock is $180 \mathrm{ft}$ at Southern Pines (R.W. Coble and J.L. Eimers, U.S. Geological Survey, written commun., 1993). about 5 miles (mi) west of Fort Bragg (fig. 1). The altitude of the basement rock at background site 1 (BGS1, fig. 1; BS1, fig. 3) is $105 \mathrm{ft}$; at SWMU 2-14 (figs. 1 and 3 ) the basement altitude is $40 \mathrm{ft}$; and at the confluence of the Cape Fear River and Rockfish Creek, approximately $13 \mathrm{mi}$ south and east of Fort Bragg, the basement altitude is $110 \mathrm{ft}$ (Brown and others, 1972).

A porous saprolite zone up to $20 \mathrm{ft}$ thick overlies much of the basement at Fort Bragg. The saprolite was formed by the weathering of the basement rocks and is mostly sand with mica and clay. The basement and saprolite are overlain by unconsolidated, interbedded sands and clays that are of late Cretaceous age. These unconsolidated sediments have been divided into two formations, the Cape Fear and Middendorf Formations (Conley, 1962; fig. 2), which are part of the thickening sedimentary wedge of the Coastal Plain. In the Sand Hills hydrologic area, the two formations show characteristics of upper delta plain deposits (Sohl and Owens, 1991).

\begin{tabular}{|c|c|c|c|c|}
\hline & $\begin{array}{l}\text { Conley (1962) } \\
\text { and this report }\end{array}$ & $\begin{array}{c}\text { North } \\
\text { Carolina } \\
\text { Office of } \\
\text { Water } \\
\text { Resources } \\
(1980)\end{array}$ & $\begin{array}{l}\text { Winner } \\
\text { and } \\
\text { Coble } \\
(1996)\end{array}$ & $\begin{array}{l}\text { Previous } \\
\text { RFI studies } \\
\text { and this } \\
\text { report }\end{array}$ \\
\hline$\underline{\mathrm{EPOCH}}$ & GEOLOGIC UNITS & \multicolumn{3}{|c|}{ HYDROGEOLOGIC UNITS } \\
\hline \multirow{3}{*}{$\begin{array}{c}\text { Late } \\
\text { Cretaceous }\end{array}$} & MIDDENDORF FORMATION & $\begin{array}{l}\text { SANDHILLS } \\
\text { AQUIFER }\end{array}$ & $\begin{array}{l}\text { BLACK } \\
\text { CREEK } \\
\text { AQUIFER }\end{array}$ & $\begin{array}{l}\text { MIDDENDORF } \\
\text { AQUIFER }\end{array}$ \\
\hline & \multirow[t]{2}{*}{ CAPE FEAR FORMATION } & \multirow[t]{2}{*}{$\begin{array}{l}\text { CAPE FEAR } \\
\text { AQUIFER }\end{array}$} & $\begin{array}{l}\text { UPPER CAPE FEAR } \\
\text { CONFINING } \\
\text { UNIT }\end{array}$ & $\begin{array}{c}\text { UPPER CAPE FEAR } \\
\text { CONFINING } \\
\text { UNIT }\end{array}$ \\
\hline & & & $\begin{array}{l}\text { UPPER CAPE } \\
\text { FEAR AQUIFER }\end{array}$ & $\begin{array}{l}\text { UPPER CAPE } \\
\text { FEAR AQUIFER }\end{array}$ \\
\hline $\begin{array}{l}\text { Pre- } \\
\text { Cretaceous }\end{array}$ & $\begin{array}{c}\text { METAVOLCANIC, } \\
\text { METASEDIMENTARY, } \\
\text { AND IGNEOUS ROCKS } \\
\text { (Basement) }\end{array}$ & BASEMENT & BASEMENT & $\begin{array}{c}\text { SAPROLITE- } \\
\text { BASEMENT AQUIFER }\end{array}$ \\
\hline
\end{tabular}

Figure 2. Generalized relation between geologic and hydrogeologic units that underlie Fort Bragg, North Carolina. 


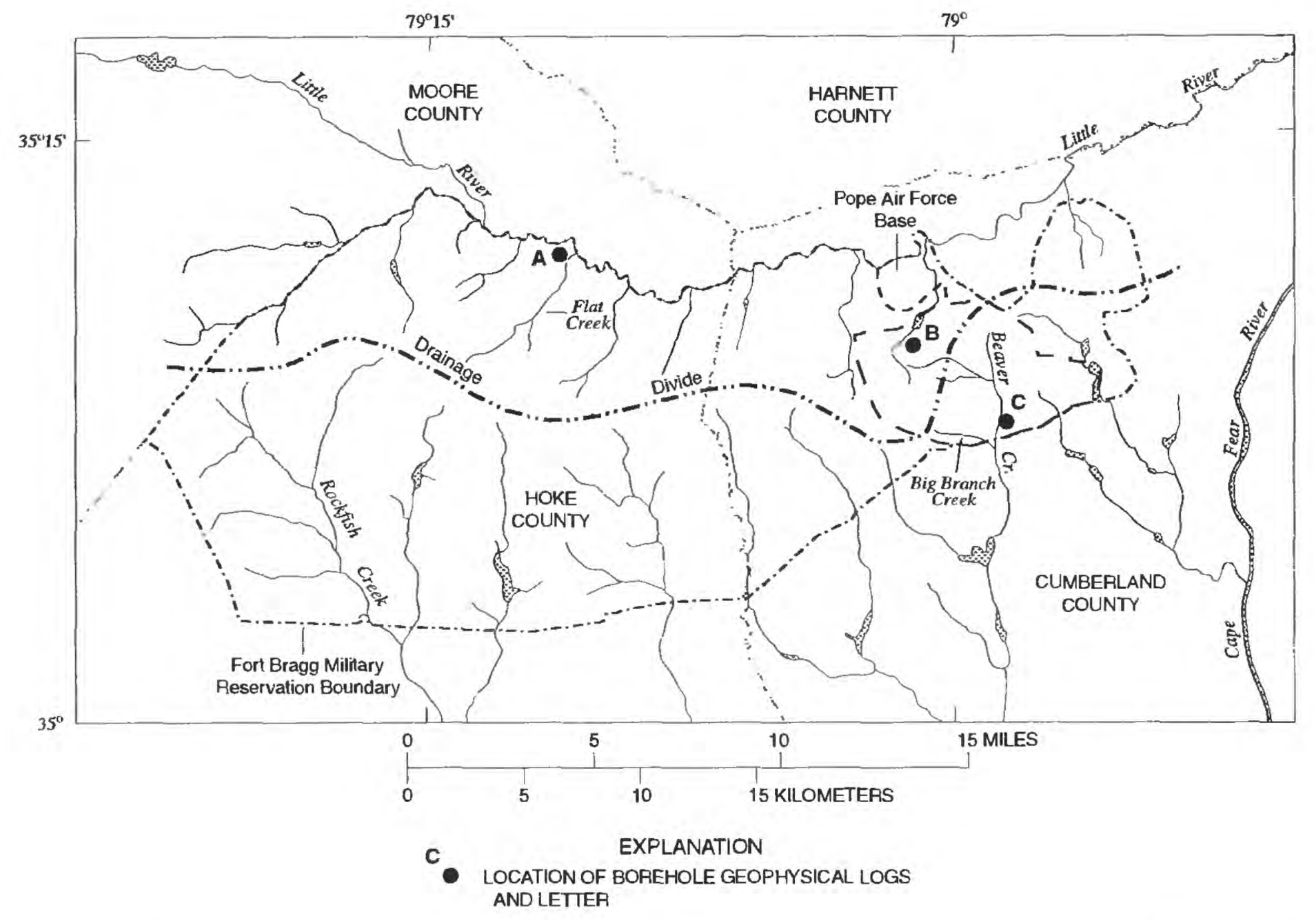

A

B

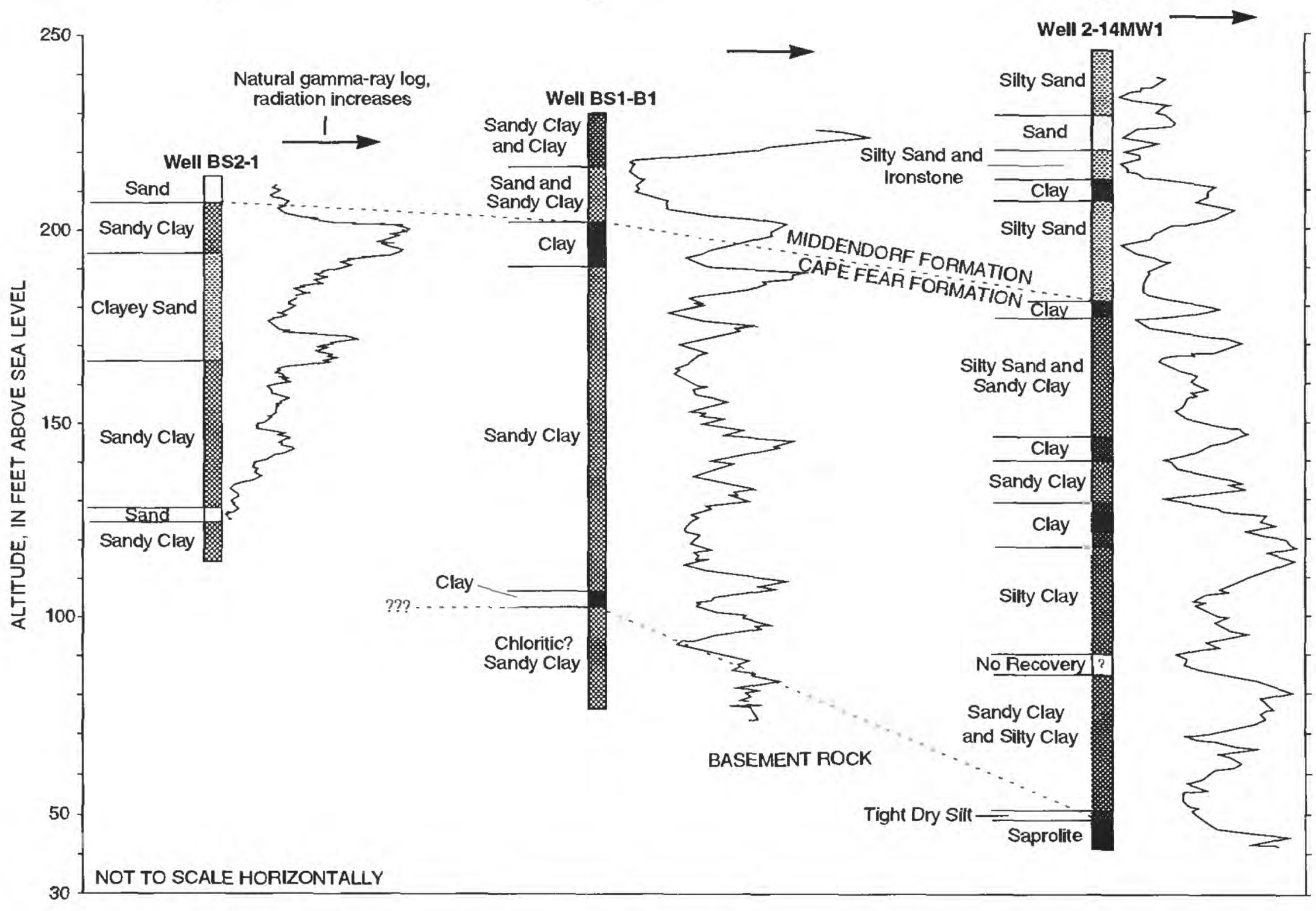

Figure 3. Surface-water drainage and geologic section A-C through Fort Bragg, North Carolina. 
The Cape Fear Formation unconformably overlies the basement and saprolite and is unconformably overlain by the Middendorf Formation (Conley, 1962; Custer, 1981; R.W. Coble, U.S. Geological Survey, written commun., 1992; figs. 2 and 3). The Cape Fear Formation is present under all of Fort Bragg. The Middendorf Formation also underlies all of Fort Bragg except in the Little River valley and the valleys of some of its tributaries and in part of the Rockfish Creek valley, where the Middendorf Formation is eroded and the Cape Fear Formation is exposed (Brown and Parker, 1985; fig. 3).

The Cape Fear Formation is composed of interbedded sand and clay. The sand units are composed mostly of fine- to medium-grained angular to subangular quartz with varying amounts of silt and clay (B.A. Lisle, U.S. Geological Survey, written commun., 1993). The interbedded clay is mostly light to dark gray with some green and red clay in the lower part of the formation. Muscovite is common in the lower two-thirds of the formation. At Fort Bragg, the top of the Cape Fear Formation is mostly clay to sandy clay that varies in thickness from 10 to as much as $40 \mathrm{ft}$ (B.A. Lisle, U.S. Geological Survey, written commun., 1993). Between Southern Pines and BGS1 (fig. 1), this formation increases in thickness from approximately 22 to $100 \mathrm{ft}$.

The Middendorf Formation is composed of interbedded fine- to coarse-grained sands and clay that are 3 to $15 \mathrm{ft}$ thick and 1 to $10 \mathrm{ft}$ thick, respectively (B.A. Lisle, U.S. Geological Survey, written commun., 1993). The soils in the Fort Bragg area are composed of weathered sediments of the Middendorf Formation, except for a few areas where the Middendorf has been eroded. In general, the Middendorf Formation is less clayey, and the quartz sand beds are generally thicker and coarser grained than is characteristic of the Cape Fear Formation. The Middendorf Formation ranges in thickness from $140 \mathrm{ft}$ beneath the upland areas to $0 \mathrm{ft}$ in the valleys. Most of the thick clay units of the Middendorf Formation occur at altitudes higher than $220 \mathrm{ft}$.

Gamma-ray logs show the alternating sand and clay beds in both formations (fig. 3). Differentiation between the Middendorf and Cape Fear Formations is made by a lithologic examination of well cuttings and cores and analyses of borehole geophysical logs (B.A. Lisle, U.S. Geological Survey, written commun., 1993). The Cape Fear Formation is generally distinguishable from the Middendorf Formation in gamma-ray logs. The background radiation of the gamma-log trace generally increases across the formation contact as a result of the increased clay content of the Cape Fear Formation relative to the Middendorf Formation (B.A. Lisle, U.S. Geological Survey, written commun., 1993; fig. 3).

The three possible freshwater aquifers in the study area are the Middendorf, the upper Cape Fear, and the saprolite-basement aquifers (B.A. Lisle, U.S. Geological Survey, written commun., 1993; fig. 2). In a regional ground-water study of the North Carolina Coastal Plain, the Black Creek and Middendorf Formations were grouped to define the Black Creek aquifer (Winner and Coble, 1996; fig. 2). Because the Black Creek Formation is absent at Fort Bragg, the Middendorf Formation has been referred to as the Middendorf aquifer in previous investigations. To maintain consistency, it is called the Middendorf aquifer in this report.

The Middendorf aquifer exists under unconfined to confined conditions. Locally, where clay beds are laterally continuous, the Middendorf aquifer is semiconfined to confined. Localized perched water tables, less than $20 \mathrm{ft}$ below land surface, have been observed from wells installed as part of the RFI studies (B.A. Lisle, U.S. Geological Survey, written commun., 1993).

The clay unit in the upper part of the Cape Fear Formation forms the Upper Cape Fear confining unit and separates the Middendorf and Upper Cape Fear aquifers (Winner and Coble, 1996). The rest of the Cape Fear Formation constitutes the Cape Fear aquifer. The Cape Fear aquifer is under confined conditions and overlies the saprolite-bedrock aquifer.

The base of the saprolite-bedrock aquifer is defined as unfractured metamorphic and crystalline Cambrian to Precambrian basement rocks (B.A. Lisle, U.S. Geological Survey, written commun., 1993). The saprolite-basement aquifer is thought to be a low producing aquifer and is not used by supply wells in the area as a sole source for water. Lithologic data from deep boreholes at Fort Bragg indicate that the saprolitebasement aquifer also is confined (D.A. Breedon, U.S. Geological Survey, oral commun., 1996).

\section{Acknowledgments}

The authors wish to thank Mr. Steven Mackmull, former Chief of the Environmental Branch, Directorate of Public Works and Environment at Fort Bragg, North Carolina, and the staff of the Environmental Branch for their cooperation during this study. The authors also wish to thank the Kansas Geological Survey for their cooperation in the collection and analysis of shallow seismic-reflection data. The USGS staff who assisted the authors with field work and preparation of the illustrations include Beth Wrege, Bruce Irvin, Rich Kessler, Ray Strain and Travis Funderburk. 


\section{SURFACE-GEOPHYSICAL METHODS}

The geophysical survey methods used in this study are discussed in the following sections. The discussion of each method includes a brief description of the equipment that was used and the operating conditions used for data collection.

\section{Shallow Seismic Reflection}

Shallow high-resolution seismic-reflection surveys using $\mathrm{P}$ - and $\mathrm{S}$-wave techniques were conducted at two background sites by the Kansas Geological Survey (fig. 1). The principles of seismic reflection are described in several books (for example, Dobrin, 1976). S-wave surveys were conducted because of their potential for increased resolution relative to $\mathrm{P}$-wave surveys in unconsolidated sediments such as those that underlie Fort Bragg. In hard rock, the $\mathrm{S}$-wave velocity is usually about one-half the $\mathrm{P}$-wave velocity; but the predominant frequency of the $S$-waves is about one-half that of the $\mathrm{P}$-waves, implying that the $S$-waves will not increase resolution in this material. In soil and unconsolidated sediments, however, S-waves can be several times slower than $\mathrm{P}$-waves and still have a similar frequency content, implying that $S$-waves can substantially increase resolution. In addition, the S-wave technique was tested because of the potential loss of the higher frequency component of P-waves in unconsolidated sediments above the water table.

The shallow seismic-reflection techniques and data processing used for higher resolution seismicreflection surveys are essentially a scaled-down version of seismic collection techniques used in the petroleum exploration industry (Yilmaz, 1987; Steeples and Miller, 1990). A summary report on the technical aspects of the seismic data collected for this study is being prepared by the KGS and is currently in press (Miller and others, in press). Data were collected with a Geometrics 2401X, 48-channel seismograph and Marks Products L-40A 100- and 50-hertz (Hz) geophones and $\mathrm{P}-44 \mathrm{10}-\mathrm{Hz}$ hydrophones. A one-fifth millisecond (ms) sampling interval resulted in a 200$\mathrm{ms}$ record with a 2,500-Hz Nyquist frequency. The best-shaped spectra to allow maximum resolution for signals generated at both background sites were provided by $200-\mathrm{Hz}$ analog low-cut filters. The analog filters have an 18-decibel (db) per octave roll-off from the selected $-3 \mathrm{db}$ points.
At least one P-wave and one S-wave 24-fold common-depth point (CDP) stacked survey was conducted at each background site. At BGS1 (fig. 1) a 53-shot-point P-wave and an 18-shot-point S-wave 24-fold CDP stacked profile was acquired using a sledge-hammer and plate as the source. A 2-ft geophone and 4-ft shot-spacing was used for the P-wave survey and a 4- $\mathrm{ft}$ geophone- and 8- $\mathrm{ft}$ shot-spacing was used for the S-wave survey. At BGS2 (fig. 1) a 24- and a 10-shot point P- and S-wave 24-fold CDP stacked profiles, respectively, were acquired using the sledgehammer plate as the source. Data at BGS2 were acquired using 4-fi geophone and 8-ft shot spacings. Post-processing of the seismic data was performed at the Kansas Geological Survey using EavesDropper and WinSeis software algorithms. All seismic-reflection survey data were elevation corrected.

Uphole-velocity surveys were conducted in wells at BGS1 and BGS2 to reliably convert two-way travel times (in milliseconds) of $\mathrm{P}$-wave reflection events on shallow seismograms to depths and to compare hyperbole fitted, normal moveout (NMO) velocities obtained from the shallow seismic-reflection data. The uphole-velocity data were acquired using a 40-Hz hydrophone lowered into wells below the water table. Data were collected at 5 - $\mathrm{ft}$ intervals from 30 to $80 \mathrm{ft}$ below land surface in BGS1 and from 30 to $90 \mathrm{ft}$ below land surface in BGS2. Multiple stacked impacts were acquired using the sledge hammer on a steel plate as the wave-source.

\section{Ground-Penetrating Radar}

Ground-penetrating radar data were collected using a Subsurface Interface Radar System (SIR)-10 with a 100-MegaHertz (MHz) shielded antenna. A $500-\mathrm{MHz}$ antenna was employed at one site. The $100-\mathrm{MHz}$ antenna was selected for this study based on results of a comparison of 100-, dual 100-, 300- and $500-\mathrm{MHz}$ antennas. The operation of the GPR has been described in several publications (for example, Davis and others, 1984). Briefly, the GPR system uses electromagnetic waves to detect irregularities and differences in the electrical properties of subsurface materials. These irregularities and differences include lithology, saturated as opposed to unsaturated material, and sediments or rocks saturated with brine or saltwater as opposed to freshwater. The SIR-10 system consists of five basic parts--the control unit, antenna, display monitor, graphic recorder (optional), and survey wheel. A 150-volt electromagnetic trigger pulse is sent to the transmitter in the antenna where it is 
transformed into a bipolar pulse and focused into the ground by the antenna. The frequency of this pulse varies with the antenna frequency. As the transmitted pulse encounters dielectric differences in the subsurface material, some of the transmitted wave is reflected back to the antenna where it is acquired by the receiver as an analog signal. The rest of the wave passes through the reflector to deeper targets. The reflected wave received by the antenna is sent back to the control unit where high-cut filters, low-cut filters, and gains are set based on the range (that is, the twoway travel time in nanoseconds (ns)) that is being sampled to increase the signal-to-noise ratio. The data are then displayed, printed, and recorded to magnetic tape. Post-processing of the GPR data was performed using WinRad.

\section{EM31 and EM34}

The operation of the EM31 and the EM34 has been described in several publications (for example, McNeil, 1981; Perry and others, 1993; and Perry, 1994). Briefly, an electrical current passing through a transmitting coil induces a magnetic field perpendicular to the coil. This magnetic field induces electrical currents in the subsurface material which, in turn, induce a secondary magnetic field that is sensed by the receiving coil. For the EM31, which is easily operated by one person, the transmitting and receiving coils are aligned in the same plane and the distance between the coils is fixed at $12 \mathrm{ft}$. When the EM31 is upright (meter is face up), the coils are horizontal to the ground and a vertical dipole is generated; when the instrument is on its side (meter faces the side), the coils are vertical to the ground and a horizontal dipole is generated. The theoretical exploration depth for the EM31 in the vertical-dipole configuration is about $15 \mathrm{ft}$, and about $7 \mathrm{ft}$ in the horizontal-dipole configuration. This instrument measures the apparent electrical conductivity (EM conductivity) of subsurface material in millisiemens per meter $(\mathrm{mS} / \mathrm{m})$ and the inphase component of the signal in parts per thousand (ppt). The inphase component is more sensitive to metallic objects than the apparent conductivity. These two measurements are displayed and also recorded in a data logger. Data for this study were collected in continuous mode with readings obtained at either 0.6- or 1.0-second (s) intervals with EM31 in the vertical-dipole position to obtain depth profiles.
The EM34 has two coils that must be manually aligned in the same plane and requires a two-person team to operate. The transmitter coil is $3.28 \mathrm{ft}$ in diameter, and the receiving coil is $1.97 \mathrm{ft}$ in diameter. The coils, as with the EM31, can be aligned either vertically or horizontally relative to the ground surface, thus producing a horizontal- and vertical-dipole field, respectively. The three coil spacings at which measurements can be obtained are 33, 66, and $131 \mathrm{ft}$. The theoretical exploration depths are about 0.75 and 1.5 times the coil spacings in the horizontal and vertical-dipole orientations, respectively. The EM34 measures the apparent EM conductivity in $\mathrm{mS} / \mathrm{m}$.

Shaded and contoured two-dimensional (2-D) plots of the EM conductivity, and inphase data from the EM31 data were created using Spyglass Transform, a data visualization software package. The $\mathrm{X}-\mathrm{Y}$ coordinates and the collected data were converted to a 2-D, 50 by 50 or 101 by 101 matrix. Blank matrix cells were filled using a kriging algorithm that minimizes the variance between groups of cells and also preserves the original data values.

\section{RESULTS OF GEOPHYSICAL INVESTIGATIONS AT SELECTED SITES}

The results and conclusions of the surfacegeophysical surveys are presented for each of the study sites. The surface-geophysical techniques that were used include $\mathrm{P}$ - and $\mathrm{S}$-wave shallow seismic-reflection surveys, ground-penetrating radar, and terrainconductivity surveys. Terrain-conductivity surveys were conducted with the EM31 and EM34.

Descriptions of the background and hydrogeology of each site precede the discussion of the surfacegeophysical survey results.

\section{Background Site 1}

Background site 1 is located in the northern part of the cantonment area of Fort Bragg (fig. 1). Initially, this was one of two sites selected as a background ground-water sampling site for comparison with results of chemical analyses of ground water obtained from RFI studies at various SWMU's. The seismic-reflection data for this site were collected in 1994. 


\section{Hydrogeology}

The altitude of the land surface at BGS1 is approximately $235 \mathrm{ft}$ above sea level (fig. 4). Lithologic data and geophysical logs from a $160-\mathrm{ft}$ deep borehole (well BS1-B1, fig. 3) indicate that the Middendorf Formation is approximately $30 \mathrm{ft}$ thick at this site. The formation consists of fine- to coarsegrained sand and silty sand with interbedded clays. Most of the lower $14 \mathrm{ft}$ of the formation consists of sand. The altitude of the top of the saturated sediments of the Middendorf Formation is approximately $225 \mathrm{ft}$. The Cape Fear Formation, which underlies the Middendorf Formation, is $100 \mathrm{ft}$ thick at the site and consists mostly of silt and clay sands interbedded with clay. The upper Cape Fear confining unit that separates the Middendorf and upper Cape Fear aquifers is approximately 10-ft thick and is composed of clay and sandy clay. Chlorite schist, interpreted as the basement rock, occurs at $135 \mathrm{ft}$ below land surface. The altitudes of the tops of the Cape Fear Formation and the basement are approximately $205 \mathrm{ft}$ and $105 \mathrm{ft}$, respectively.

\section{Results and Conclusions}

Three P-wave seismic sources were tested at BGS1--a 30:06 downhole rifle, a 5.5-pound (lb) sledge hammer with a steel plate coupled to the ground, and a 12-gauge auger gun. The 30:06 proved to be the best source, followed closely by the 5.5-lb sledge hammer (Miller and others, in press). Because data could be collected more rapidly and with similar results as the 30:06, the 5.5- $\mathrm{lb}$ sledge hammer and plate were used as the seismic source for the seismic-reflection surveys. Shallow seismic P-wave reflection data were collected along a 242-fi long north-south line (BGS1-1) and a 410-fi long east-west line (BGS1-2) (fig. 4). P-wave uphole-velocity data were collected from well BS1-B1 located near the south end of BGS1-1 (fig. 4).

Several coherent reflectors between the two-way travel times of 35 and $80 \mathrm{~ms}$ were observed in the processed 24-fold CDP stacked P-wave data collected along line BGS1-1 (fig. 5A). The NMO velocity of 4,000 ft/s obtained from a 35- to 40-ms reflection in individual shot gathers (that is, individual traces gathered from one shot) is close to the average velocity of 4,100 feet per second (ft/s) obtained from the uphole-velocity survey for the upper $80 \mathrm{ft}$.

The depths of the reflection events are calculated by dividing the two-way travel time by 2 and multiplying the resulting number by the velocity. Hughes (1985) demonstrated that reflection depths calculated using the average velocity are generally within 10 percent of the reflection depths calculated using the stacking velocity (that is, the velocity calculated for the interval between each reflection event). Because the purpose of this study was to only explore the usefulness of shallow seismic-reflection to delineate the shallow subsurface geology, average velocity was used to estimate the depth of the reflection events. The minimum theoretical bed thickness for shallow seismic-reflection surveys is about $6 \mathrm{ft}$ for the frequencies used in this velocity interval (Miller and others, in press).

The two-way travel time of the uppermost reflection event along most of survey line BGS1-1 is approximatcly $40 \mathrm{~ms}$ and decreases to $35 \mathrm{~ms}$ near the north end of the survey line (fig. 5A). These two-way travel times correspond to depths of approximately $70 \mathrm{ft}(35 \mathrm{~ms})$ and $80 \mathrm{ft}(40 \mathrm{~ms})$ (fig. 5A). Examination of lithologic and borehole geophysical logs from well BS1-B1 (fig. 3), located near the south end of BGS1-1, indicates that the top of a 6- to 10-ft thick clay bed occurs at $80 \mathrm{ft}$ below land surface and is also the depth at which mica was first detected. Thus, the 35- to 40-ms reflection event may indicate that the upper surface of this clay bed is more shallow at the northern end of the survey line, $70 \mathrm{ft}$ below land surface, than at the southern end of the survey line, $80 \mathrm{ft}$ below land surface.

A discontinuous series of reflections at 45-ms, and 55-ms and 60-ms reflection events correspond to depths of approximately 92,112 , and $123 \mathrm{ft}$ below land surface, respectively. The 45- and 55-ms reflections coincide approximately with the base of two clay layers 6 to $10 \mathrm{ft}$ thick, and the $60-\mathrm{ms}$ reflection coincides with the top of a clay unit directly above the proposed basement surface (fig. 3). Finally, the 70-ms reflection event corresponds to a depth of approximately $140 \mathrm{ft}$ below land surface and is within $5 \mathrm{ft}$ of what has been proposed as the top of the basement and probably represents the interface between the Cape Fear Formation and either the saprolite or basement. Processed 12-fold CDP stacked P-wave data (fig. 5B) collected along BGS1-2 (fig. 4) were considerably noisier than the 24-fold CDP data collected along BGS1-1 (fig. 5A). Coherent reflection events with two-way travel times greater than $60 \mathrm{~ms}$ were not observed in the 12-fold CDP data. 


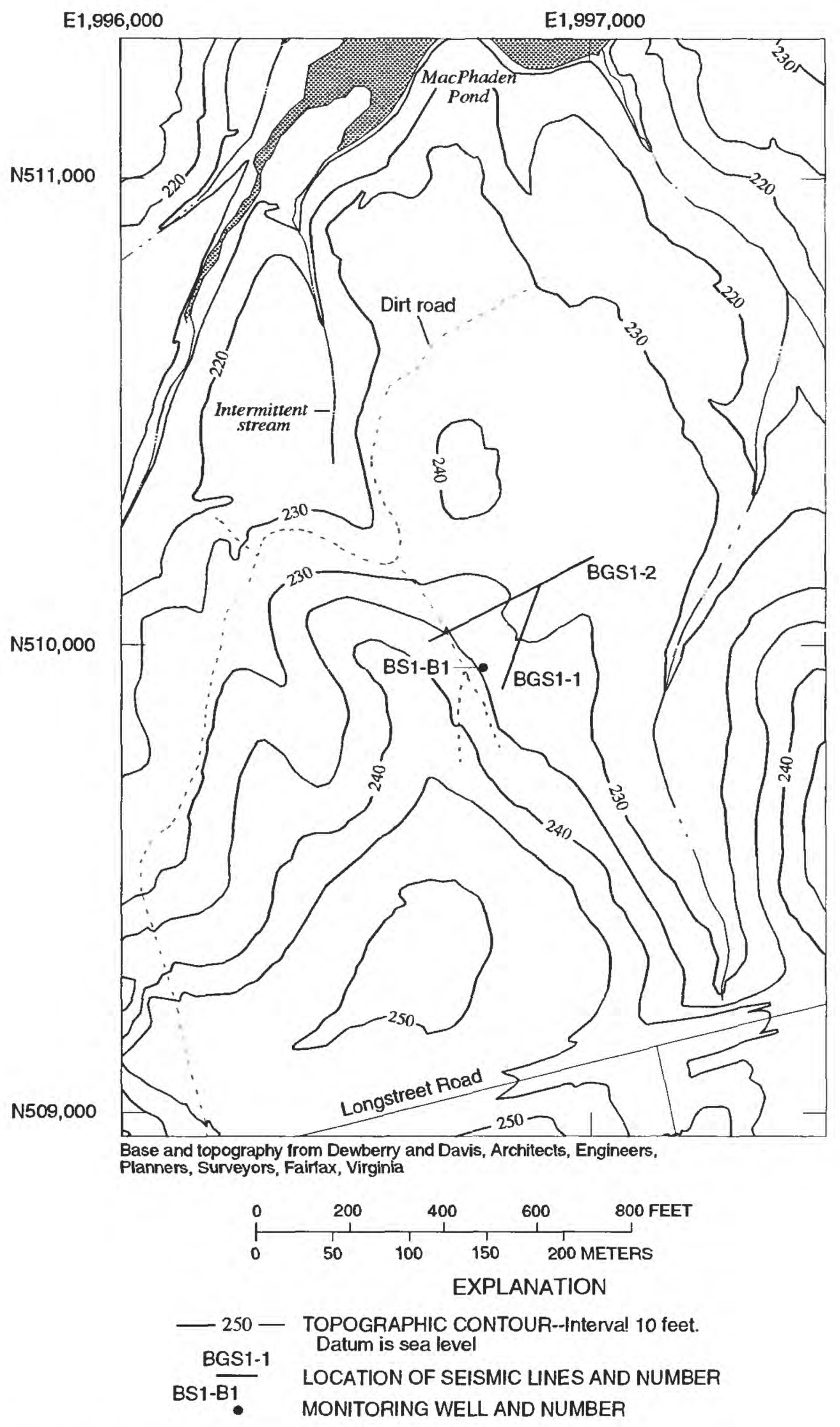

Figure 4. Background site 1, Fort Bragg, North Carolina. 


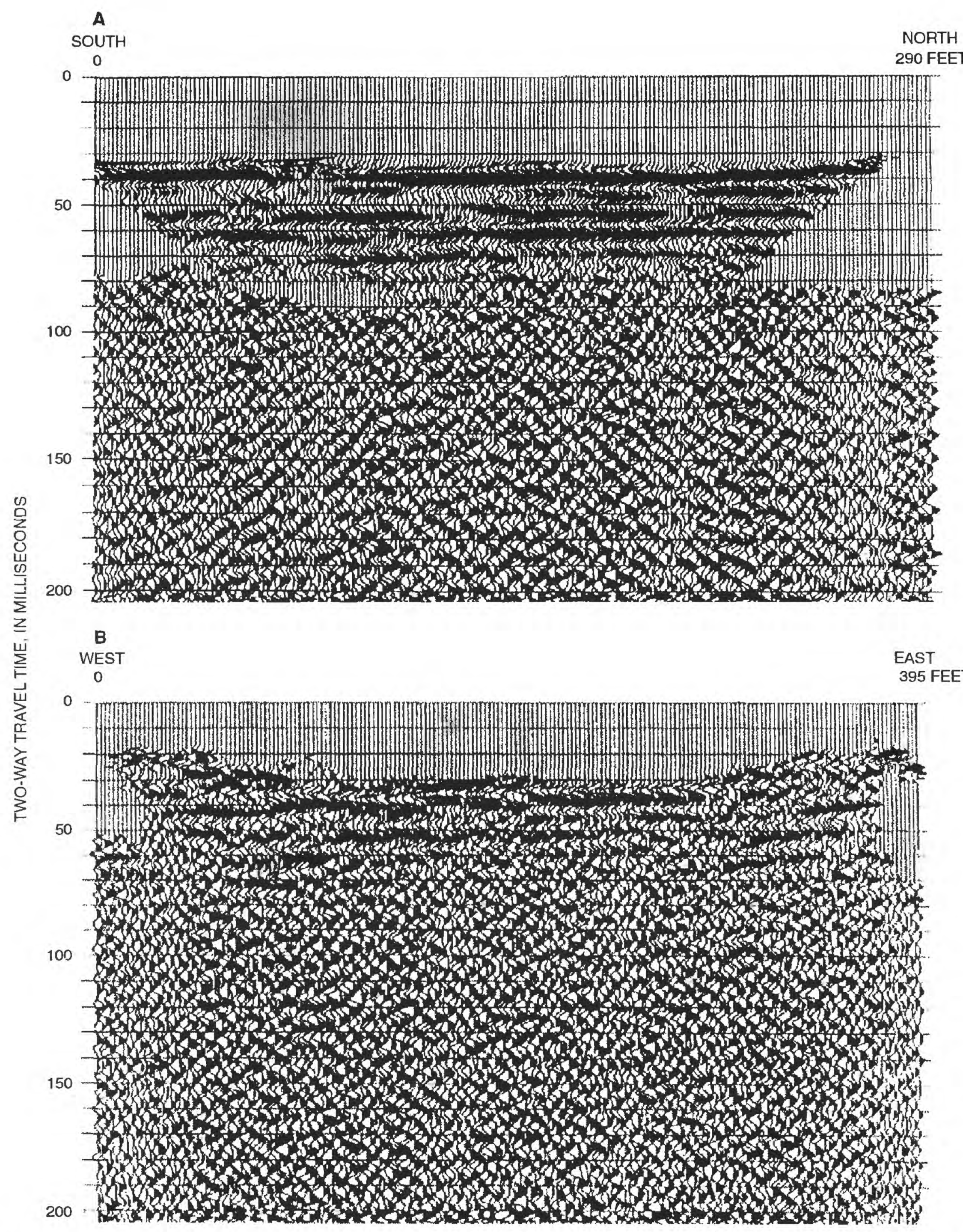

Figure 5. Shallow seismic-reflection, processed, (A) 24-fold CDP stacked data from BGS1-1 and (B) 12-fold CDP stacked data from BGS1-2 at Fort Bragg, North Carolina. (Locations of BGS1-1 and BGS1-2 are shown in figs. 1-4.) 
Shallow seismic S-wave data also were collected along BGS1-1. Some individual S-wave shot gathers indicate that a reflection event occurs at about $240 \mathrm{~ms}$, which corresponds to a depth of $156 \mathrm{ft}$ using a calculated NMO, S-wave velocity of $1,300 \mathrm{ft} / \mathrm{s}$. However, this reflection event was not present in many of the shot gathers and no coherent reflection events were observable in the processed 24-fold CDP stacked $\mathrm{S}$-wave profile. The $\mathrm{S}$-wave survey was plagued by narrow band-width problems. The S-wave generator used for this survey was a 5.5-lb sledge hammer that was used to strike, at an angle, a metal plate coupled to the ground. The movement of the plate, while being struck with the hammer, partially decoupled the S-wave source. This decoupling caused a loss of the high frequency component of the S-wave source and resulted in a severe narrowing of the $S$-wave band width. The frequency content of a seismic wave constitutes its band width. Consequently, loss of the high frequency component decreases band width which, in turn, decreases resolution. In addition, the decoupling generated P-waves that interfered with the S-waves.

P-wave reflection surveys effectively mapped the lateral continuity of interbedded sand and clay units at least $6 \mathrm{ft}$ in thickness and deeper than $70 \mathrm{ft}$. The 24 -fold, P-wave data also effectively delineated the basementsaprolite surfaces. The 24-fold, P-wave data were considerably less noisy and provided more information at depth than the 12-fold, P-wave data. Due to problems with the S-wave generator, 24-fold S-wave data showed no coherent subsurface reflection events. However, new S-wave sources are currently available along with horizontal geophone arrays designed for S-wave surveys that might be worth testing at Fort Bragg, because of the potential increase in resolution of S-waves relative to $\mathbf{P}$-waves in unconsolidated sediments.

\section{Background Site 2}

Background site 2 is located near the northern boundary of Fort Bragg (fig. 1). Initially this was one of two sites selected as a background ground-water sampling site for comparison with results of chemical analyses of ground-water obtained from RFI studies at various SWMU's. The seismic-reflection data were collected in 1994, and the ground-penetrating radar and terrain conductivity data were collected in 1996.

\section{Hydrogeology}

The altitude of the land surface at well BS2-1 is approximately $210 \mathrm{ft}$ (fig. 6). Lithologic and geophysical logs from an approximately 100-ft deep borehole in this area (BS2-1; fig. 3) indicate that the sediments of the Middendorf and Cape Fear Formations consist mostly of sand with varying amounts of clay interbedded with clay and sandy clay (fig. 3). A 10-ft thick clay unit approximately $10 \mathrm{ft}$ below land surface is interpreted as the top of the Cape Fear Formation. Thus, the Middendorf Formation at this site is approximately $10 \mathrm{ft}$ thick. Material from the saprolite and basement was not identified in the $100-\mathrm{ft}$ deep borehole indicating that the altitude of the basement surface is less than $114 \mathrm{ft}$.

\section{Results and Conclusions}

Geophysical data were collected along BGS2-1 a 200-ft survey line (fig. 6). Processed P-wave data (24-fold stacked CDP) collected at BGS2 show that coherent reflection events occur at two-way travel times of 45,55 , and $65 \mathrm{~ms}$ (fig. 7). Deconvolution processing was not performed on the seismic-reflection data; thus, the 55- and 65-ms reflections are separate events and not a polarized signal of one event at $60 \mathrm{~ms}$. The calculated NMO velocity of the 45 -ms reflection event was approximately $4,200 \mathrm{ft} / \mathrm{s}$, which agrees well with the average velocity of $4,500 \mathrm{ft} / \mathrm{s}$ obtained from the uphole-velocity survey conducted in well BS2-1 (fig. 6). The 45-ms reflection event corresponds to a depth of $95 \mathrm{ft}$ based on NMO velocity and $102 \mathrm{ft}$ based on the average velocity, which is the depth of the deepest well at this site. Thus, it is not known to what feature of the Cape Fear Formation this reflection event corresponds. A 35-ms reflection observed on some individual P-wave shot gathers coincides with a lithologic transition from sandy clay to sand in the Cape Fear Formation at approximately $74 \mathrm{ft}$ below land surface. The 35-ms reflection did not, however, stack coherently in the CDP stacked profile. Based on the average velocity, the 55- and 65-ms reflection events correspond to depths of approximately 125 and $145 \mathrm{ft}$, respectively. These two reflection events probably are from the saprolite and bedrock surfaces and indicate that the altitude of the base of the Cape Fear Formation is approximately $100 \mathrm{ft}$. 


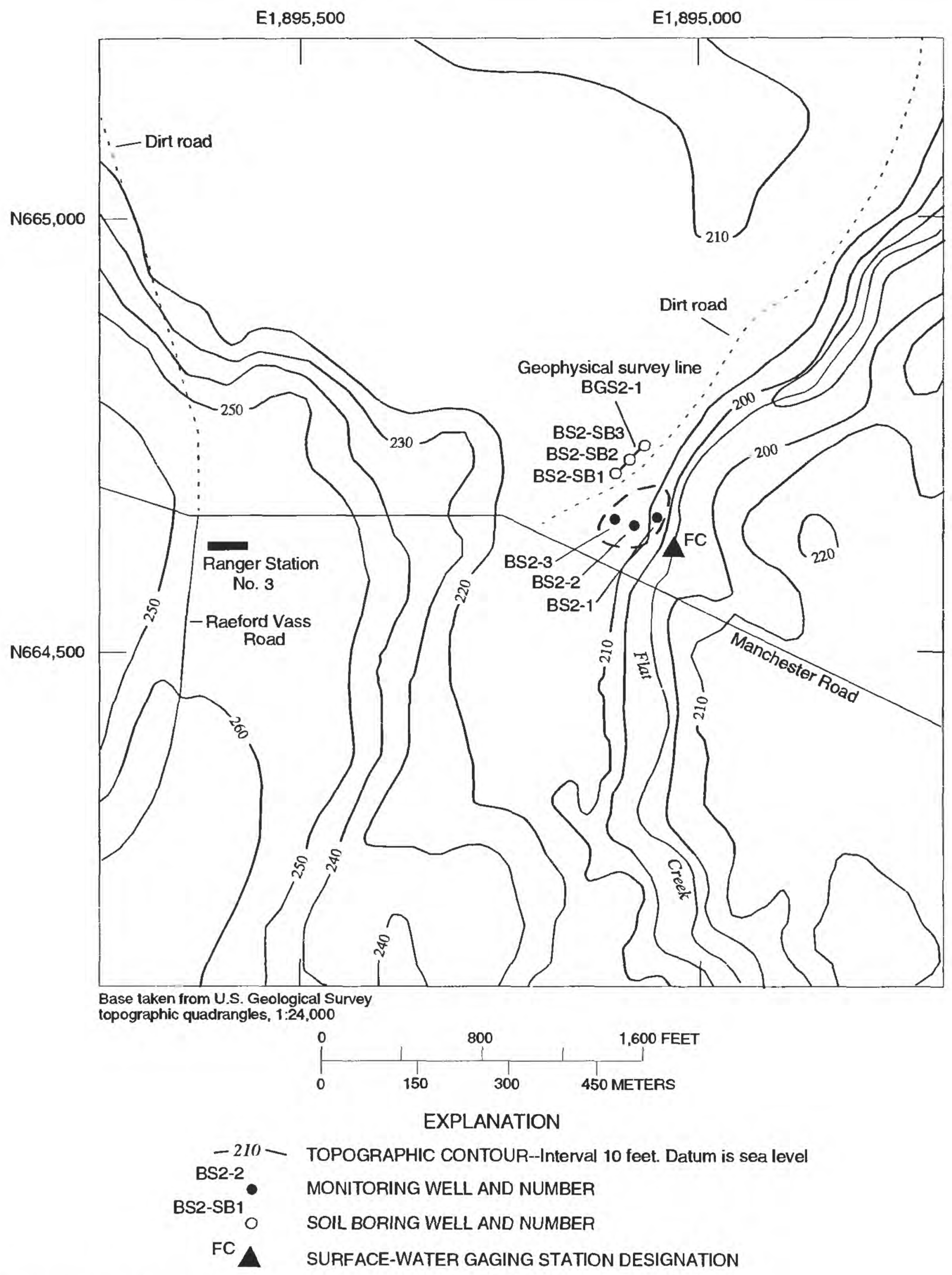

Figure 6. Background site 2, Fort Bragg, North Carolina. 


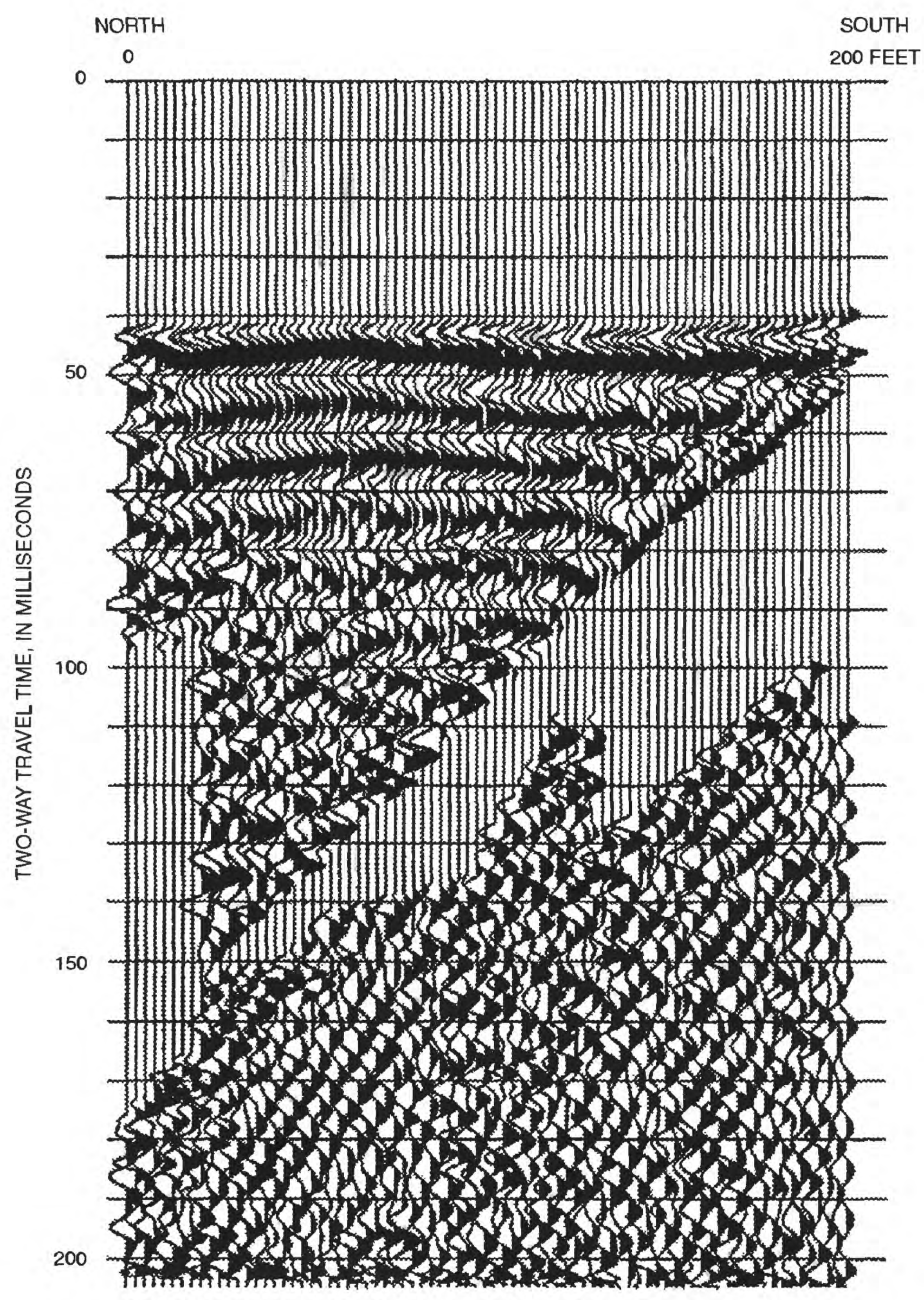

Figure 7. Shallow seismic-reflection, processed, 24-fold CDP stacked data from BGS2-1 at Fort Bragg, North Carolina. 
The GPR data show that the radar signal did not effectively penetrate past $45 \mathrm{~ns}$ (fig. 8A). A prominent, dark, continuous series of reflectors with two-way travel times that vary from approximately 15 to $20 \mathrm{~ns}$ persists across approximately three-fourths of the survey line from southwest to northeast. A less pronounced set of discontinuous reflections with twoway travel times that increase from approximately 30 to $45 \mathrm{~ns}$ also occurs across approximately three-fourths of the survey line from southwest to northeast, respectively. To better understand the reflection profile acquired with the GPR, three 10-ft cores (BS2-SB1 BS2-SB3) were taken along BGS2-1 (fig. 6).

Examination of the cores indicated that the 8- to $10-\mathrm{ft}$ section of the Middendorf Formation present at this site consists of interbedded sands and clays that range from less than 1 to $3 \mathrm{ft}$ in thickness (fig. 9). The top of a clay unit consistent with the Cape Fear confining unit was observed in the two southwesternmost cores at 8 to $9 \mathrm{ft}$ below land surface. The saturated thickness of the Middendorf aquifer, immediately above the Cape Fear confining unit, was less than $1 \mathrm{ft}$ in these two cores and was not observed in the northeastern most core where the top of the confining unit was not present (fig. 9). Based on the moist condition of the sediment in the core and the alternating sand and clay, a dielectric constant of 10 was chosen to convert two-way travel times to depth.

Two tan, clayey-sand units in the upper $5 \mathrm{ft}$ thicken toward the northeast and the sand unit between them thins at the northeast end of the BGS2-1 (fig. 9). The estimated depth of the prominent 15- to 20-ns series of reflections is 2.3 to $3.1 \mathrm{ft}$ and the estimated depth of the less prominent 30- to 45-ns set of reflections is approximately 4.7 to $7 \mathrm{ft}$ (fig. 8A). The depth and the spacing between these two sets of GPR reflections is consistent with the interval occupied by the two thin, tan, clayey-sand units and the light medium-grained sand unit that lies between them. The attenuation of the radar signal by the upper tan clayey unit is the most likely reason for the weak set of reflections received from the lower tan clayey unit. At the northeast end of BGS2-1 is a "reflection-free" zone that probably results from an increased attenuation of the radar signal by the thickening of the clay units and the less resolvable dielectric difference offered by the significantly thinned sand unit that lies between them.

The EM31 profile along BGS2-1 shows a slight increase in EM conductivity from 3 to $4 \mathrm{mS} / \mathrm{m}$ toward the northeast; the inphase component was fairly flat at
$5.5 \mathrm{ppt}$ except for a slight rise to $5.7 \mathrm{ppt}$ near the southwest end of BGS2-1 (fig. 8B). The trend in the EM34-conductivity data, configured for the shallowest sampling depth, (horizontal, 33-ft coil spacing), also shows a slight increase in EM conductivity toward the northeast (fig. 8C). The EM31 and EM34 data provide corroborative evidence of a general increase in the EM-conductive properties of shallow subsurface material along BGS2-1 which is consistent with the thickening of the shallow subsurface clay units. The gradual increase in EM conductivity also provides evidence that the attenuation of the GPR signal in the northeastern part of BGS2-1 was due to the thickening of these clays.

The profiles of the EM34 data collected along BGS2-1 have overall higher EM conductivities with increased spacing between the coils and are also higher in the vertical dipole than in the horizontal-dipole configuration for a given coil spacing (fig. 8C). An overall increase in EM conductivity with increased depth of sampling is typical, because the electromagnetic field samples the overall conductivity of successively larger regions of the subsurface. However, the EM34- and EM31-conductivity profiles do not distinguish between interbedded sands and clays.

Shallow seismic data from BGS2 indicate that $P$-wave reflection is most useful for mapping the lateral continuity of interbedded sand and clay units greater than $6 \mathrm{ft}$ in thickness and deeper than $70 \mathrm{ft}$ below land surface, and for mapping the basement surface and the saprolite zone. The S-wave was not effective with the S-wave source and geophone arrays available at the time of this study.

The GPR mapped the lateral continuity of a very shallow sand bounded by thin clay units. The depth to which the radar signal penetrated was dependent on the proximity of clay layers to the surface and their thickness.

Finally, data collected from the EM31 and EM34 provided supporting evidence for the thickening shallow subsurface clays and the attenuation of the GPR signal. However, the EM-conductivity data were not directly useful in defining alternating sand and clay units in the shallow subsurface at this site. Layered modeling programs are available that could be tested to see if further manipulation of the EM31 and EM34 data can provide some general insight into the subsurface geology. 


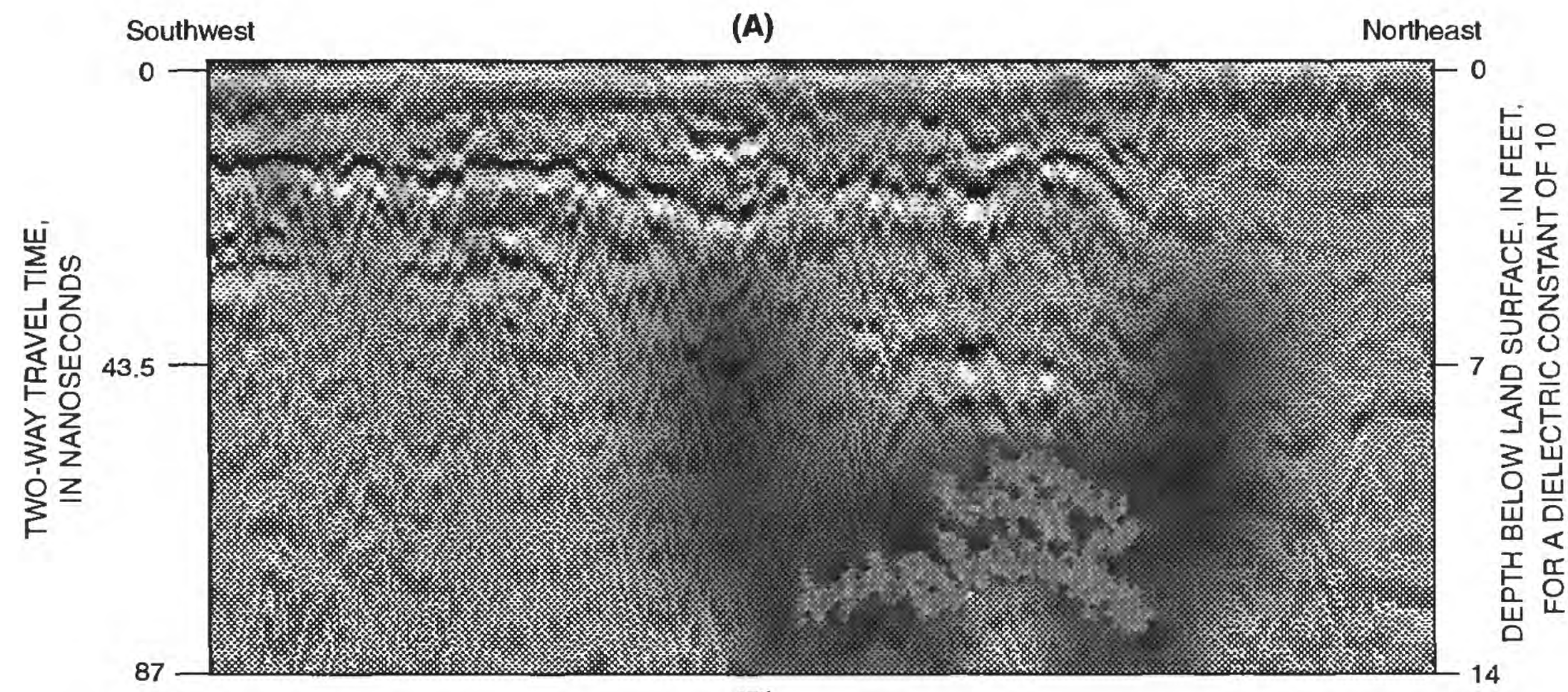

(B)

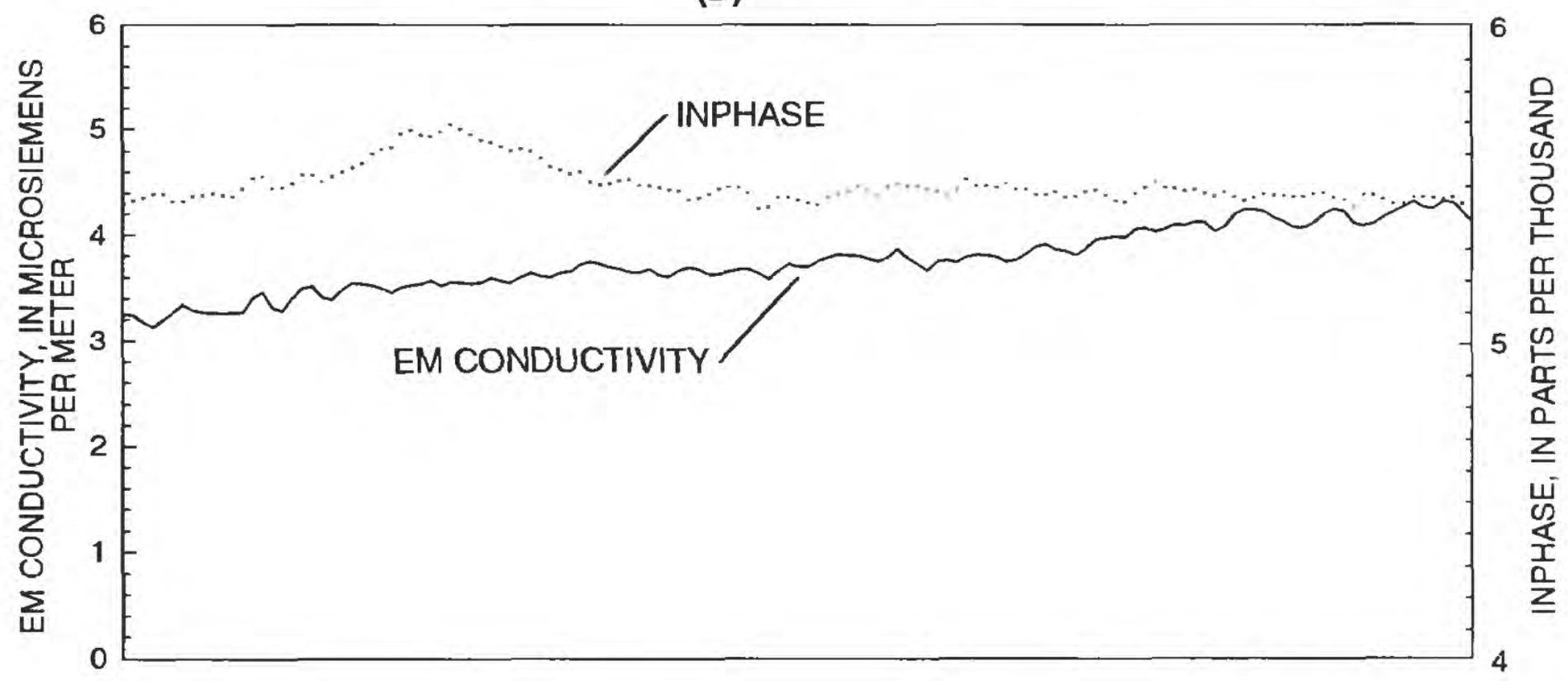

(C)

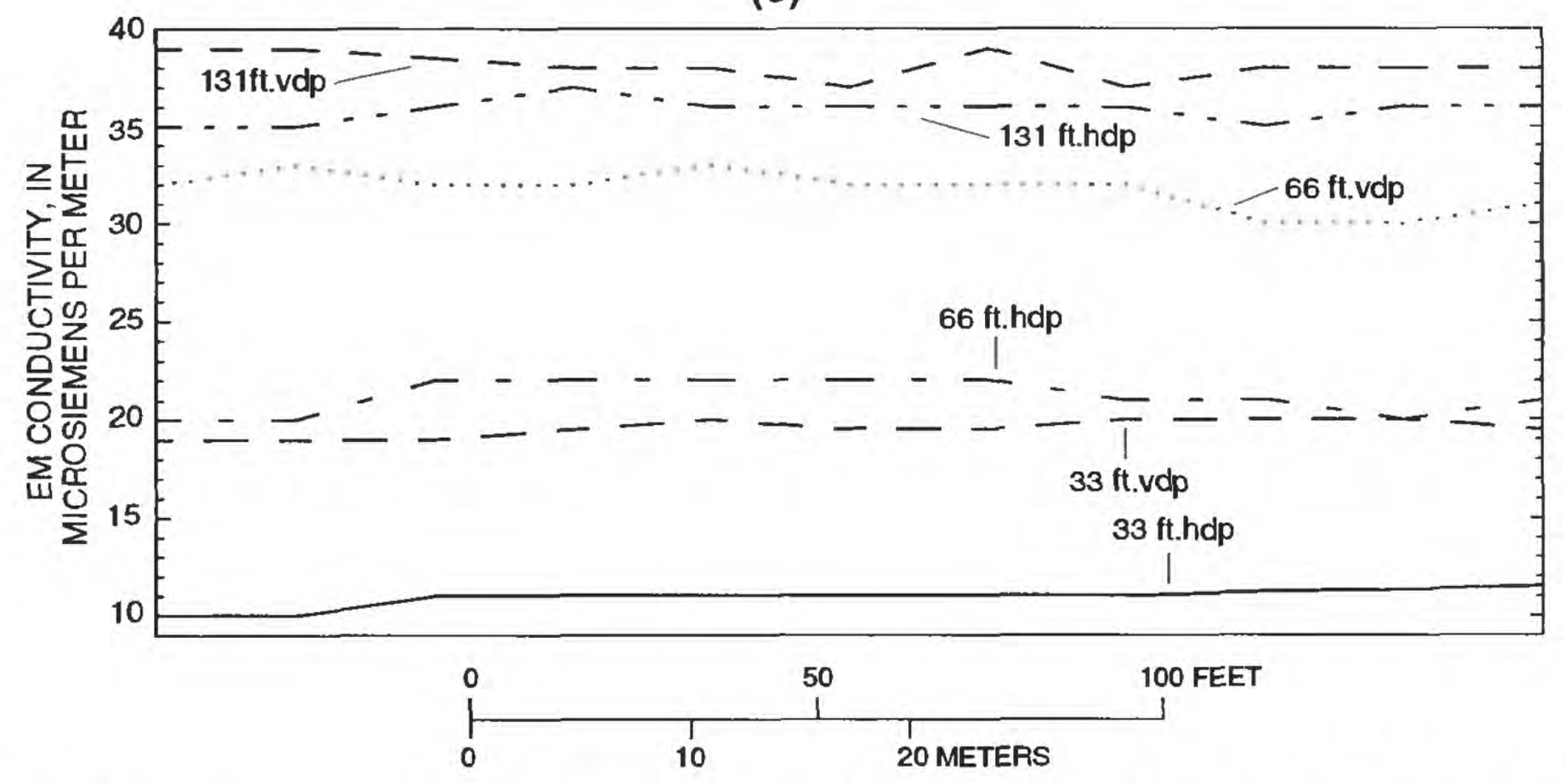

Figure 8. (A) Unprocessed GPR, (B) EM31-vertical dipole, and (C) EM34-conductivity data at BGS2. (vdp, Vertical-dipole position; hdp, horizontal-dipole position.) 


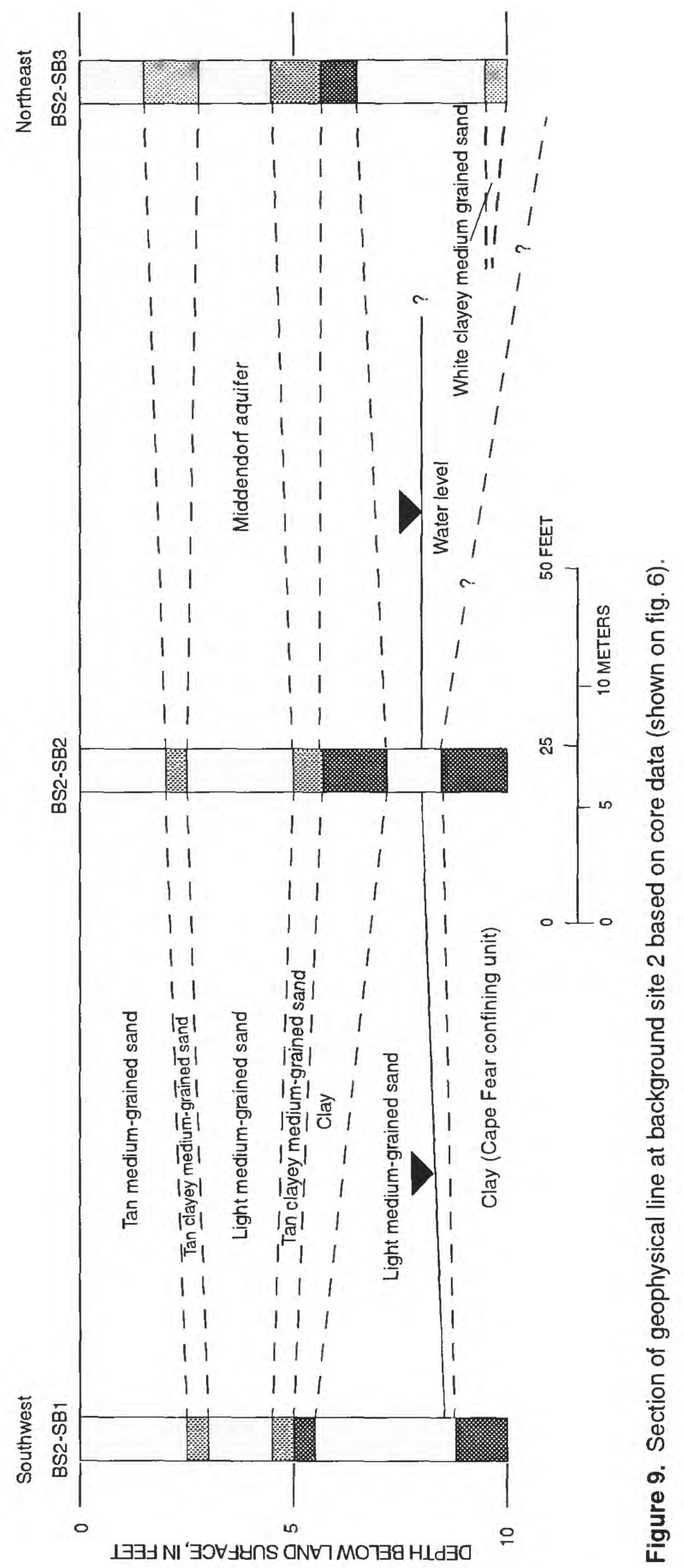




\section{SWMU 2-14}

SWMU 2-14 (fig. 1) contains three landfills that were part of a previous RFI study. Individually, the landfills are referred to as landfills $2,14 \mathrm{a}$, and $14 \mathrm{~b}$. A previously unrecognized landfill or extension of one of the landfills at SWMU 2-14 was inadvertently discovered during the drilling of a borehole in 1995. Subsequently, a geophysical study was conducted to define the areal extent of this landfill.

\section{Background and Hydrogeology}

Landfill 2, the oldest of the three landfills at SWMU 2-14, covers approximately 59 acres and includes two smaller landfills, $14 \mathrm{a}$ and $14 \mathrm{~b}$, which were established on top of landfill 2. These two landfills occupy an area of about 5 acres (fig. 10). SWMU 2-14 is bordered by the flood plain of Beaver Creek to the west. The east-central part of landfill 2 is bordered by a large military salvage and demobilization yard where damaged or inoperable vehicles are parked. Landfills $14 \mathrm{a}$ and $14 \mathrm{~b}$ border the northwest corner of the salvage yard. The vehicle salvage yard and the fence surrounding it were established after landfill 2 was deactivated but before landfills $14 \mathrm{a}$ and $14 \mathrm{~b}$ were established. Landfill 2 was operated between 1951 and 1955; no records exist of the types of waste placed at the site (Kearney, Inc., and DPRA, Inc., 1988). Landfills 14a and 14b were operated between 1985 and 1986. SWMU 2-14 was studied as part of an RFI study in 1994.

Landfill cover (less than $2 \mathrm{ft}$ thick) and debris associated with SWMU 2-14 are present only at landfills $14 \mathrm{a}$ and $14 \mathrm{~b}$. Waste materials in these two landfills include asphalt, wood scraps, scrap metal, insulation, paint cans, and rags. In addition, terrain-conductivity surveys of SWMU 2-14, conducted as part of the RFI study in 1994, indicated that EM-conductivity anomalies occurred over landfills $14 \mathrm{a}$ and $14 \mathrm{~b}$. The land surface elsewhere at SWMU 2-14 consists of undisturbed sediments of the Middendorf Formation.

The land surface at SWMU 2-14 generally slopes westward toward Beaver Creek and decreases from 240 to $185 \mathrm{ft}$ in altitude (fig. 10). Landfills $14 \mathrm{a}$ and $14 \mathrm{~b}$ form topographical lobate features that interrupt the westward slope. Borehole geophysical and lithologic logs at SWMU 2-14 indicate that the Middendorf Formation varies in thickness from $61 \mathrm{ft}$, near the southern boundary of landfill 14b, to $26 \mathrm{ft}$ near Beaver Creek (S.L. Harden, U.S. Geological Survey, written commun., 1996). The Middendorf Formation is composed of interbedded sands, silty and clay sands, and clay (fig. 3; well 2-14MW1, fig. 10). The sand and clay units vary from 3 to $25 \mathrm{ft}$ in thickness. The saturated thickness of the Middendorf aquifer ranges from 22 to $29 \mathrm{ft}$ and ground-water flow is to the west. The altitude of the top of the Cape Fear confining unit varies from 167 to $177 \mathrm{ft}$ in altitude. The saprolite zone underlying the Cape Fear Formation occurs at an altitude of $40 \mathrm{ft}$ based on geophysical and lithologic logs of well 2-14MW1 at this site (fig. 3).

\section{Results and Conclusions}

During the RFI study, a well (2-14MW19, fig. 10) was drilled at the northwest corner of the fence surrounding the military salvage yard as a background well. Landfill was penetrated $15 \mathrm{fi}$ below land surface during the installation of the well. High readings from an organic vapor analyzer (OVA) made it necessary to plug the auger while completing the well; thus, the thickness of the landfill is unknown. There were no records of the landfills at SWMU 2-14 extending into this area. In order to identify the extent of this newly identified landfill area, GPR, EM31, and EM34 data were collected.

The transects along the perimeter and inside the vehicle salvage yard where GPR data were collected are shown in figure 10. EM31 data were collected only along the labeled transects (A-A', B-B', and C-C', fig. 10). Conductive interference from the close proximity of vehicles allowed for only one line of EM31 data $\left(\mathrm{C}-\mathrm{C}^{\prime}\right)$ to be collected inside the vehicle salvage yard. The EM34 was tested along transect A-A'. Continuous drifting of the meter readings during its operation rendered it unusable for this study site. Based on borehole geophysical logs and lithologic logs, a dielectric constant of 10 was chosen to convert the twoway travel times of the GPR data to depths (fig. 11A).

A series of dark reflections with two-way travel times extending from approximately 30 to 80 ns below the surface, persists across the GPR record of sections A-A' and B-B' (fig. 11A). A mostly reflection-free (white) area occurs under these reflections indicating attenuation of the radar signal. The deepest set of reflections in the record are centered on the well (2-14MW19) where landfill was first detected. These reflections form a trough-shaped feature with a depth of approximately $13 \mathrm{ft}(80 \mathrm{~ns})$. This trough-shaped feature is interpreted as landfill cover. Some faint (lighter colored) reflections that occur under this trough have two-way travel times of more than $150 \mathrm{~ns}(23 \mathrm{ft})$. The deeper reflections associated with this trough may 


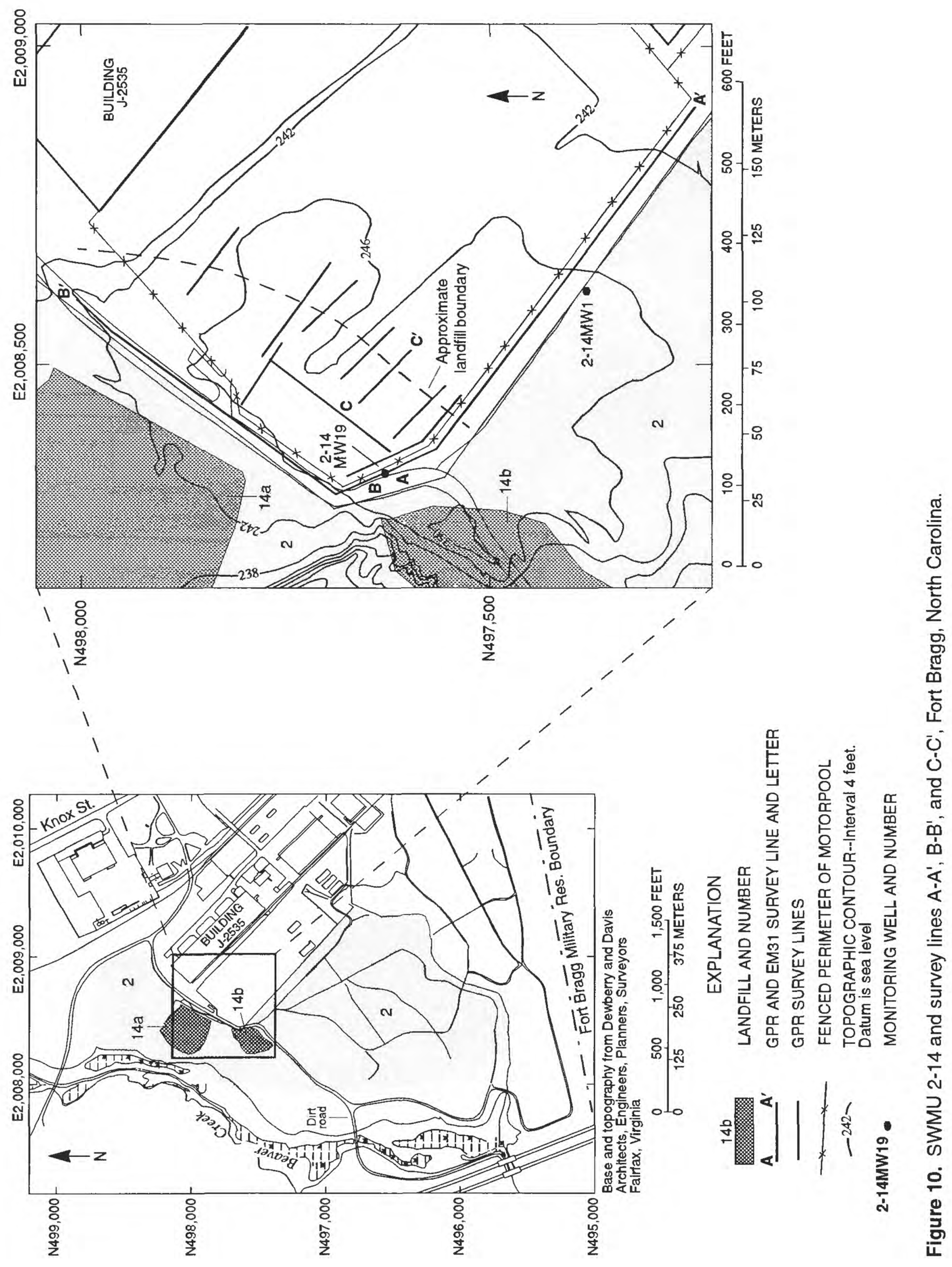



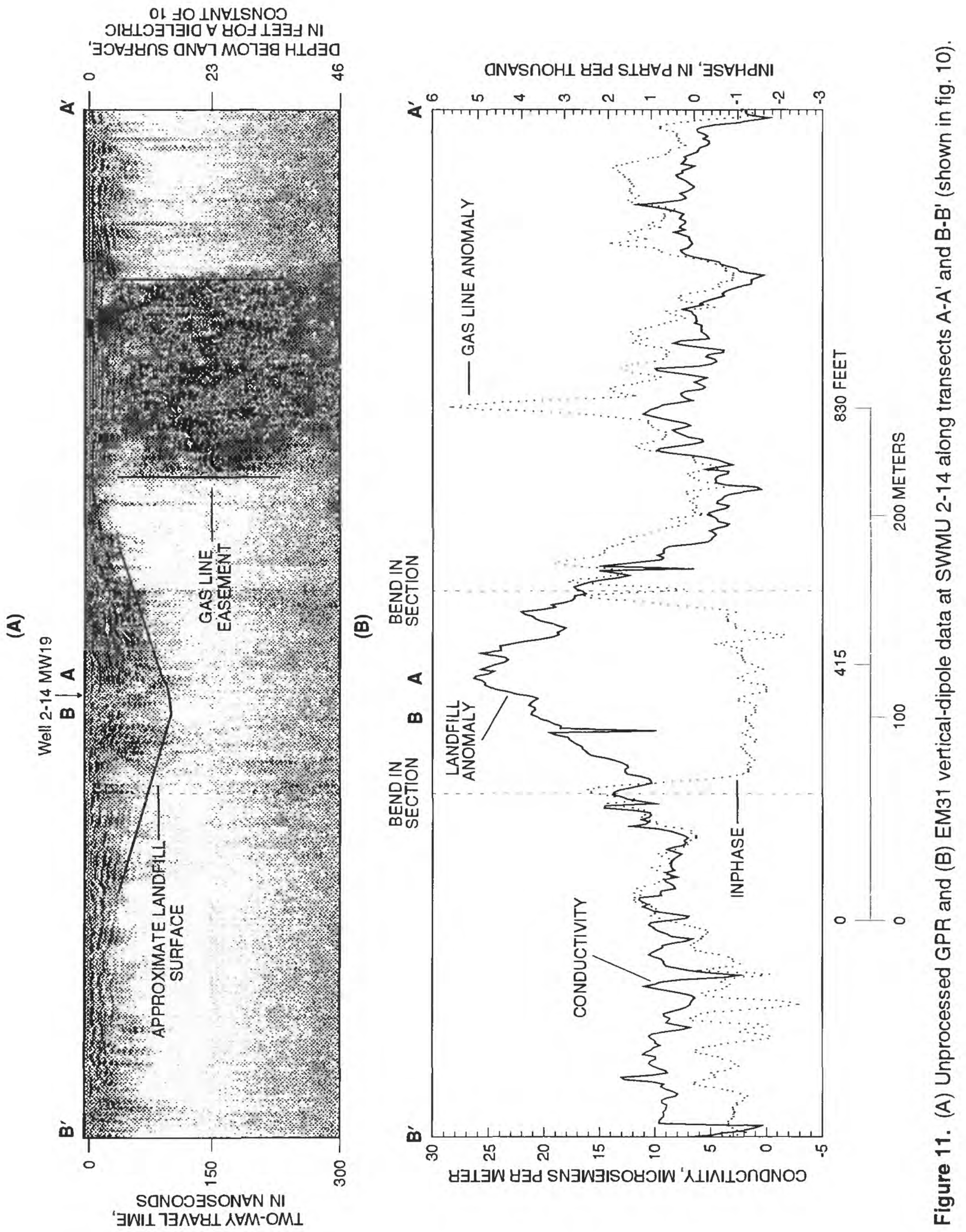
indicate that the landfill was backfilled with a sandier material than was originally there, thus allowing for deeper penetration of the radar signal. The central part of the A-A' survey line contains a series of noisy events that create a jumbled vertical dark area extending from approximately 30 to $300 \mathrm{~ns}$ (fig. 11A). This part of the survey line corresponds to the location of a buried gas pipe. The conductive nature of the pipe or backfill for the pipe is probably responsible for the noise in the GPR record.

The relatively reflection-free area that occurs throughout the GPR record, except in the vicinity of the buried pipe, indicates that the material under the landfill and the adjacent subsurface material are electrically conductive (fig. 11A). The attenuation of the GPR signal throughout the rest of the GPR record indicates that much of the subsurface material has a high clay content. Thus, the landfill material and the surrounding subsurface material are indistinguishable with the GPR record at this site.

Two prominent features are present in the EM31 data (fig. 11B) that are coincident with the area of the trough-shaped and jumbled, dark vertical features in the GPR record. The first feature is an EM conductivity high centered on the axis trough-shaped feature in the GPR record. The EM conductivity rises from a fluctuating background that varies between 0 and $10 \mathrm{mS} / \mathrm{m}$ to more than $25 \mathrm{mS} / \mathrm{m}$ and indicates that the material under the landfill cover is significantly more conductive than the surrounding subsurface material.

GPR and EM31 profiles also were taken within the salvage yard and yielded similar results. Drilling substantiated the extent of the landfill (fig. 10) determined by the surface-geophysical surveys. The second prominent feature in the EM31 data is an inphase anomaly spike that rises to nearly $6 \mathrm{ppt}$ and is centered on the area of the GPR record where the gas pipe is buried (fig. 11B). This is a typical response of a buried metal object, such as a pipe. The depth of the anomaly could be calculated if the dimensions of the pipe were known.

The GPR was useful for mapping the extent of landfill cover at this site, which contained a trench-type landfill. However, attenuation of the radar signal by the landfill and adjacent subsurface clays made the two mediums indistinguishable by GPR. The EM31 provided useful evidence that the EM conductivity of the material under the landfill cover was different from the surrounding subsurface material. The GPR was also useful for identifying a disturbed area where a utility pipe had been buried, and the EM31 was useful in identifying the location of the pipe. Without the corroborating EM31 data, the anomalous trough and jumbled vertical anomaly would have just been a GPR anomaly (fig. 11). The EM31 data provided important corroborating and enhanced evidence that supported the interpretation of the GPR data. The GPR was least affected by cultural noise (power-lines, metal fences, and parked vehicles) followed by the EM31 and EM34 (table 1).

Table 1. Usefulness of GPR, EM31, and EM34 techniques for environmental studies at SWMU 2-14

[ft, feet; NA, not applicable]

\begin{tabular}{ccc}
\hline Technique & \multicolumn{1}{c}{ Pros } & Cons \\
\hline GPR & $\begin{array}{l}\text { Define areal extent of landfill cover. Identify } \\
\text { disturbed areas where utilities are buried. Real- } \\
\text { time interpretative data. Was not significantly } \\
\text { affected by cultural noise. }\end{array}$ & $\begin{array}{c}\text { Radar-signal attenuated by landfill material. } \\
\text { Needed independent method to confirm that } \\
\text { material under the landfill was different } \\
\text { from adjacent subsurface material. Did not } \\
\text { detect buried utility. }\end{array}$ \\
EM31 & $\begin{array}{l}\text { EM-conductivity profile useful for distinguishing } \\
\text { landfill material from adjacent subsurface } \\
\text { material. Inphase signal useful for detecting } \\
\text { metallic utilities. }\end{array}$ & $\begin{array}{l}\text { Was not usable within 15-20 ft of metal fences } \\
\text { and parked vehicles. Need to know dimen- } \\
\text { sions of buried object to estimate depth. }\end{array}$ \\
EM34 & NA &
\end{tabular}




\section{SWMU 5}

SWMU 5 (fig. 1) was one of the sites investigated as part of an RFI study conducted by the USGS. EM31 data were collected at this site to compare with EM34 data collected as part of the RFI study and also to determine whether a more detailed survey and computer-graphic imaging might provide a more useful means to aid in the selection of sampling sites.

\section{Background and Hydrogeology}

SWMU 5 (fig. 12) is an abandoned landfill that occupies approximately 7 acres in the central part of the cantonment area, 2 mi southeast of BGS1 (fig. 1). The boundary proposed for SWMU 5 as the result of a RCRA Facilities Assessment (RFA) study (Kearney, Inc., and DPRA, Inc., 1988) is shown in figure 12. This landfill was operated from 1966 to 1967 and was part of an RFI study conducted during 1993-96. The landfill is unlined; the thickness of the landfill cover varies from approximately $1 \mathrm{ft}$ to $5 \mathrm{ft}$. Surface debris at the landfill includes bricks, boards, angle iron, bed springs, shingles, coal, asphalt, and concrete. A buried stove and refrigerator also were exposed at the land surface. To better delineate the landfill, EM31 and EM34 surveys were conducted.

The area around SWMU 5 (fig. 12) has a similar hydrogeological framework as BGS1. The average altitude over most of SWMU 5 is about $240 \mathrm{ft}$. Geophysical and lithologic logs from selected boreholes across the southern boundary of SWMU 5 (fig. 13) indicate that the Middendorf Formation is approximately 30 to $50 \mathrm{ft}$ in thickness. About $900 \mathrm{ft}$ northwest of SWMU 5 at well 5MWD1 (fig. 13), the land surface altitude is $270 \mathrm{ft}$ and the Middendorf Formation is approximately $80 \mathrm{ft}$ thick. Lithologic logs indicate that the sand units consist mostly of fine to medium sand and silt and clayey sand with interbedded clay. The sand and clay beds range from less than 1 inch to more than $10 \mathrm{ft}$ in thickness. Locally, moderately continuous clays can support perched water tables and also act as confining units in the Middendorf Formation. Most of the thick clay units are in the upper part of the Middendorf Formation at altitudes higher than $220 \mathrm{ft}$. Continuous clay layers were not observed across SWMU 5 at altitudes between 190 and $220 \mathrm{ft}$. Thus, at least part of the Middendorf aquifer underlying SWMU 5 is under unconfined to semiconfined conditions. The top of the Cape Fear confining unit was identified in wells at altitudes of 185 to $190 \mathrm{ft}$. The altitude of the water levels in wells surrounding the landfill and installed in the Middendorf aquifer varied from $210 \mathrm{ft}$ to $225 \mathrm{ft}$ from south to north, indicating a general southward movement of ground water toward Beaver Creek (B.A. Lisle, U.S. Geological Survey, written commun., 1994).

\section{Results and Conclusions}

The EM31-conductivity and inphase data are displayed as 2-D matrix interpolated screened and contoured images in figure $14 \mathrm{~A}$ and $\mathrm{B}$, respectively. This figure shows similar areal distributions of the conductivity and inphase anomalies at SWMU 5. The inphase data indicate that metallic debris is buried in the landfill. The background EM-conductivity and inphase values over most of SWMU 5 are close to $0 \mathrm{mS} / \mathrm{m}$ and 0 ppt, respectively. Negative EM-conductivity and inphase anomalies, less than $-5 \mathrm{mS} / \mathrm{m}$ and $-3 \mathrm{ppt}$, respectively, occur just within the northeast boundary and several hundred feet northwest of the SWMU 5 boundary. A high positive EM-conductivity $(40 \mathrm{mS} / \mathrm{m})$ and inphase (9 ppt) anomaly occurs along the southwest boundary of the survey area, which is bordered by a fence, and is also northwest of the boundary. This anomaly also appears to extend west past the edge of the EM31 survey boundary.

Results from an EM34 survey conducted as part of an RFI investigation in 1991 at SWMU 5 are shown in figure 15. This survey was conducted before the installation of the fence that runs along the southwestern boundary of the EM31 survey area. For this survey the EM34 was conducted with a coil spacing of $33 \mathrm{ft}$ and with the coils in the vertical-dipole orientation, resulting in a theoretical exploration depth of about $50 \mathrm{ft}$. The contoured EM34 data show an area of anomalous EM conductivity that coincides with the conductive area defined by the EM31 survey (fig. 14A). The EM34 data also indicate that this anomaly persists south of the fence that limited the southwestern extent of the EM31 survey. Thus, the indication from the EM 31 data that the landfill may extend southwest of the fence line is confirmed by the earlier EM34 data. Construction and metallic debris in test boreholes and excavation pits in the area of increased EM conductivity defined by the EM31 and EM34 surveys demonstrates that the landfill extends farther west than previously thought (fig. 12). 


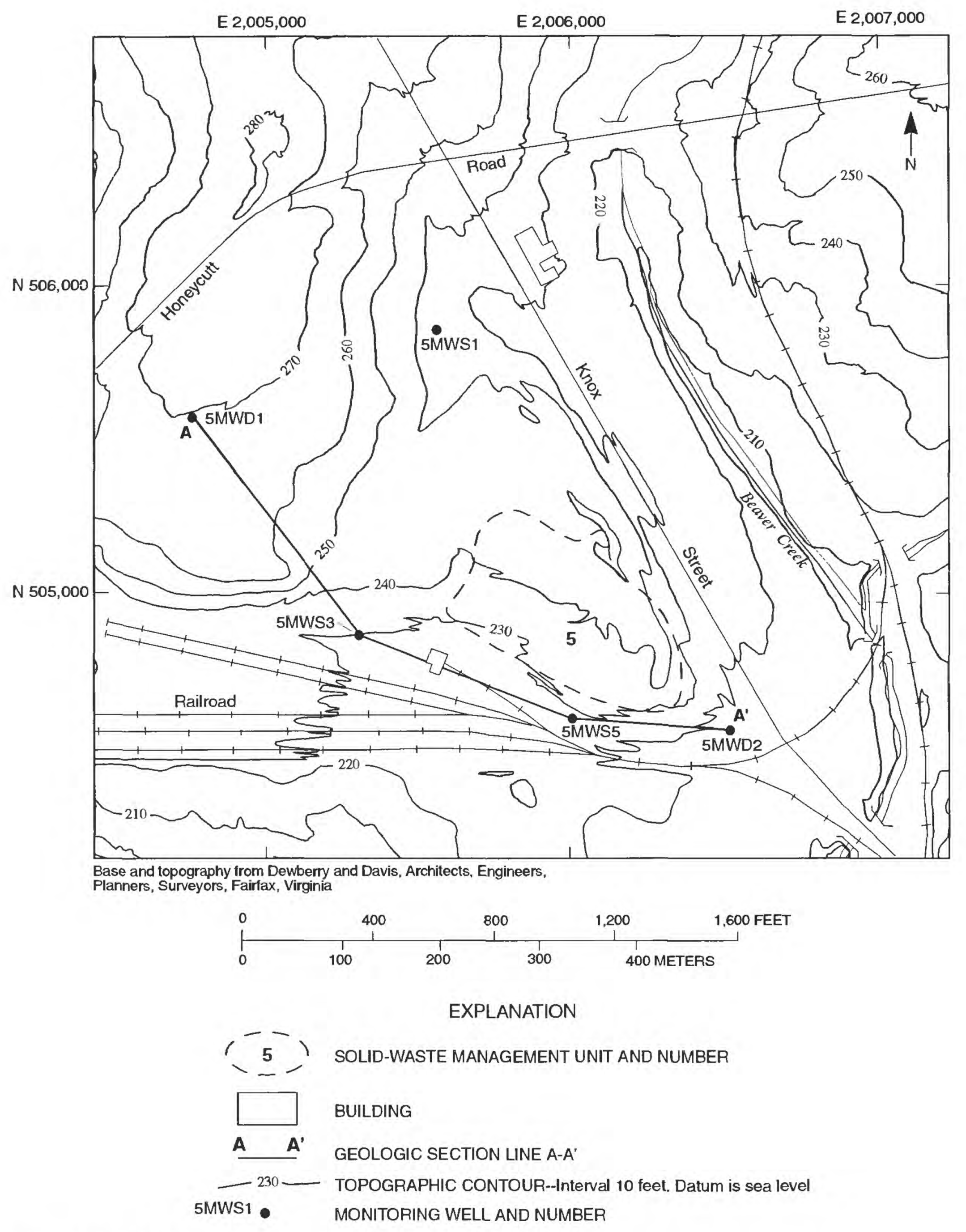

Figure 12. SWMU 5, Fort Bragg, North Carolina. 


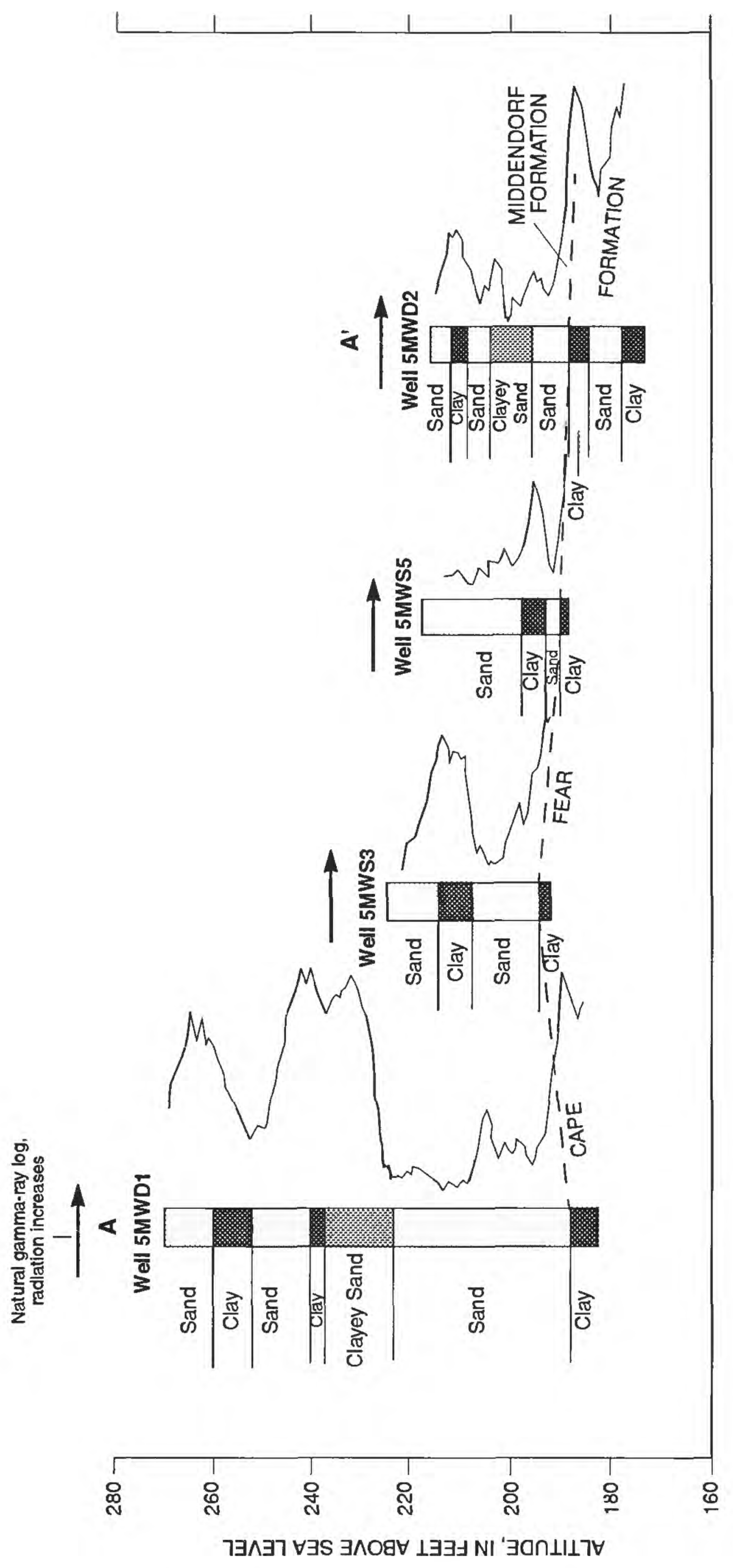

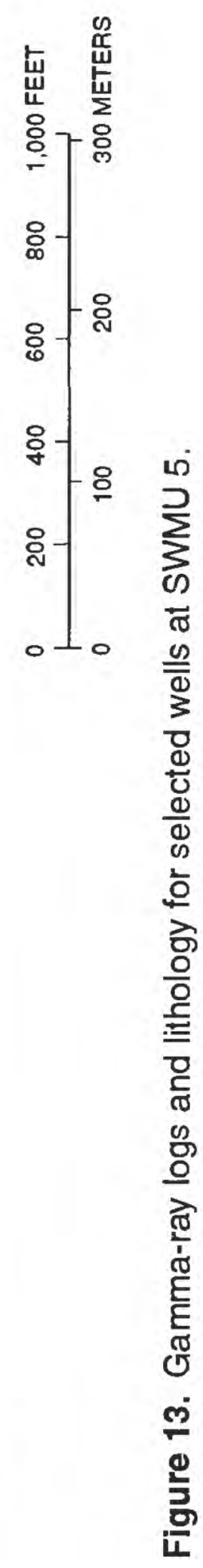



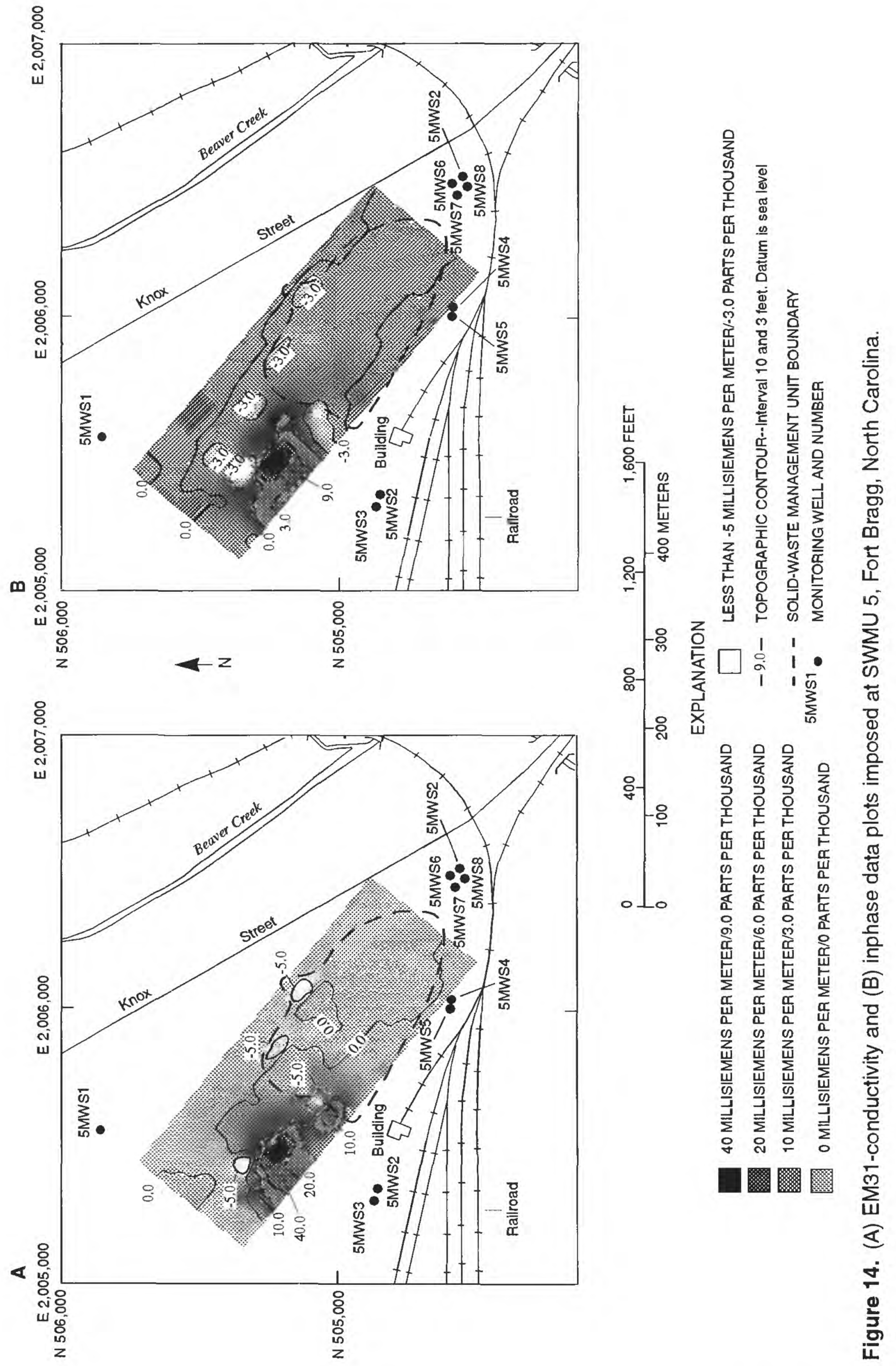


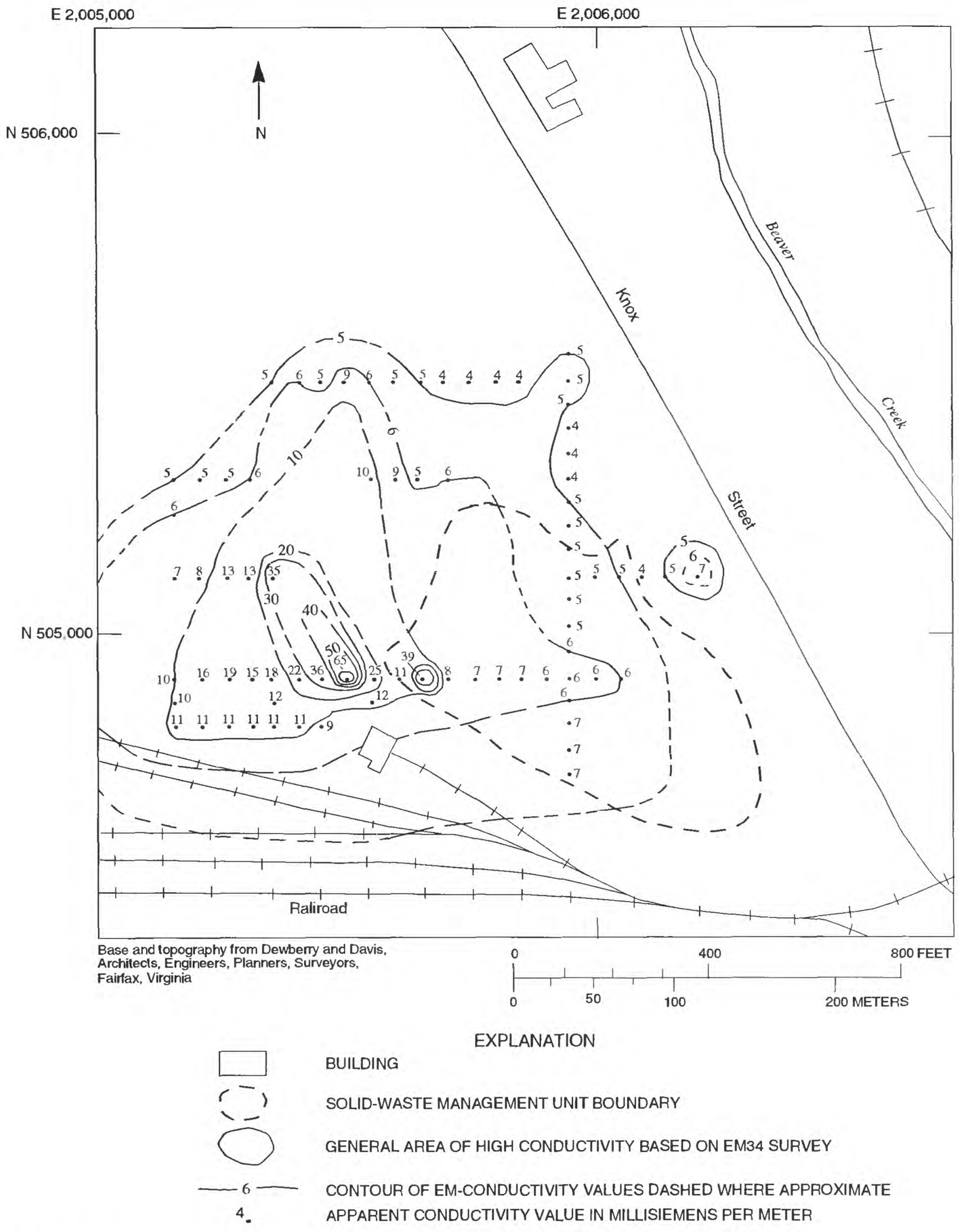

Figure 15. Conductivity values collected in 1991 using the EM34 configured for a theoretical exploration depth of 50 feet. 
The EM31 and EM34 were useful investigative techniques for identifying areas with anomalous EM conductivities associated with landfill material at SWMU 5 (table 2). In addition, the inphase component of the EM31 signal was useful in conjunction with EM conductivity for identifying areas where metallic objects were most likely buried. 2-D, matrix-interpolated plots of EM data offer a visual advantage in identifying where areas of anomalous EM conductivity occur in a landfill and also where these anomalies may extend outside of the area being surveyed.

Table 2. Usefulness of EM31 and EM34 techniques for environmental studies at SWMU 5

\begin{tabular}{|c|c|c|}
\hline Technique & Pros & Cons \\
\hline EM31 & $\begin{array}{l}\text { Surveys can often be } \\
\text { conducted by one } \\
\text { person in a day. EM } \\
\text { data can be readily } \\
\text { transformed into 2-D } \\
\text { images useful for } \\
\text { identifying areal extent } \\
\text { of landfill material and } \\
\text { areas within landfill } \\
\text { where debris is } \\
\text { concentrated. }\end{array}$ & $\begin{array}{l}\text { Provides limited } \\
\text { depth information } \\
\text { on buried debris. }\end{array}$ \\
\hline EM34 & $\begin{array}{l}\text { Useful for identifying } \\
\text { areas of high } \\
\text { conductivity associated } \\
\text { with landfill debris. } \\
\text { Can be used to find } \\
\text { deeper subsurface } \\
\text { anomalies than the } \\
\text { EM31. }\end{array}$ & $\begin{array}{l}\text { Requires a two- } \\
\text { person team for } \\
\text { operation. Data } \\
\text { collection takes } \\
\text { more time than the } \\
\text { EM31, especially } \\
\text { if measurements } \\
\text { are made with } \\
\text { multiple coil } \\
\text { spacings at each } \\
\text { station. }\end{array}$ \\
\hline
\end{tabular}

\section{SWMU 1}

SWMU 1 is an abandoned landfill and dumpsite located near the south-western boundary of the cantonment area at Fort Bragg (fig. 1). This site is part of a current RFI study and was selected to test the utility of the EM31 and ground-penetrating radar as siteassessment tools for identification and location of a complex landfill site.

\section{Background and Hydrogeology}

SWMU 1 covers approximately 94 acres in the cantonment area (fig. 16) and is part of a current RFI study. Most of SWMU 1 is now paved and contains three large vehicle maintenance facilities. The landfill was active from the early 1940's to 1951 and was used mostly to dump general refuse and incinerator ash. The composition of the ash is not known, but may include laboratory waste from a medical pathology and a veterinary-pathology incinerator that are no longer in operation. Waste at the site includes wood, rubber debris, and wire. Soil borings indicate that landfill material is located between 0 and $12 \mathrm{ft}$ below land surface under most of the site.

SWMU 1 is located in an upland area at Fort Bragg and is bordered by Gruber Road to the north and Big Branch Creek to the east and one of its tributaries to the south (fig. 16). The topography of the landfill ranges in altitude from $240 \mathrm{ft}$ at the southern end of the landfill along an intermittent tributary of the Big Branch Creek to $340 \mathrm{ft}$ to the north by Gruber Road. Based on a deep borehole at SWMU 3 just south of SWMU 1, the altitude of the top of the Cape Fear Formation is $190 \mathrm{ft}$ (S.L. Harden, U.S. Geological Survey, written commun., 1996). Thus, the Middendorf Formation probably varies from approximately 60 to more than $140 \mathrm{ft}$ in thickness at SWMU 1. Geophysical and lithologic logs obtained from boreholes at SWMU 1 show that the Middendorf Formation is composed of interbedded sand beds 5 to $20 \mathrm{ft}$ thick and clay beds 2 to $15 \mathrm{ft}$ thick (fig. 17). The sand is mostly fine to medium grained with varying amounts of clay.

\section{Results and Conclusions}

The matrix-interpolated EM31-conductivity and inphase data are displayed as 2-D interpolated screened and contoured images in figure $18 \mathrm{~A}$ and $\mathrm{B}$, respectively. Background conductivity values less than $10 \mathrm{mS} / \mathrm{m}$ and inphase values less than $0 \mathrm{ppt}$ occur throughout most of the southern region of the survey area. Elevated conductivity and inphase values cover similar areas. However, the highest conductivity anomalies are centered on the abandoned dumpsite in the northwest corner of the survey area and on the site of the old incinerator, the two-lobed anomaly in the center of the survey area; the highest inphase anomalies are in the northeast corner and near the westcentral boundary of the survey area. Because the inphase signal is more sensitive to metal, more metallic debris may be buried where the high inphase anomalies occur. The EM31 data also indicate that the landfill may extend farther north and west than the surveyed area. The EM31 data match fairly well the pattern of refuse that was in test boreholes across SWMU 1, and metallic debris occurred near the inphase anomaly in the northeast section of the survey area. 


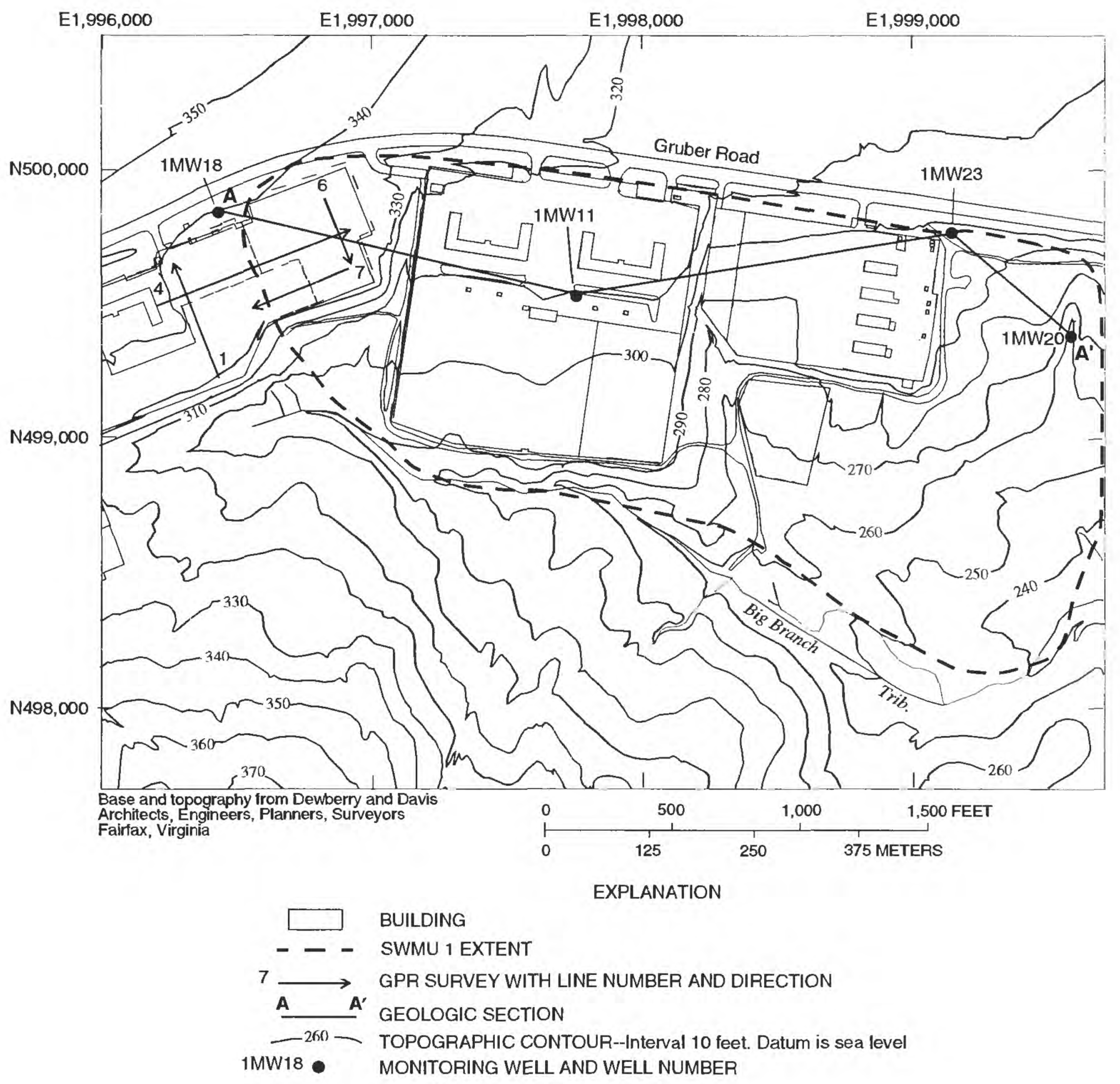

Figure 16. SWMU 1, Fort Bragg, North Carolina, and geologic section A-A'. 


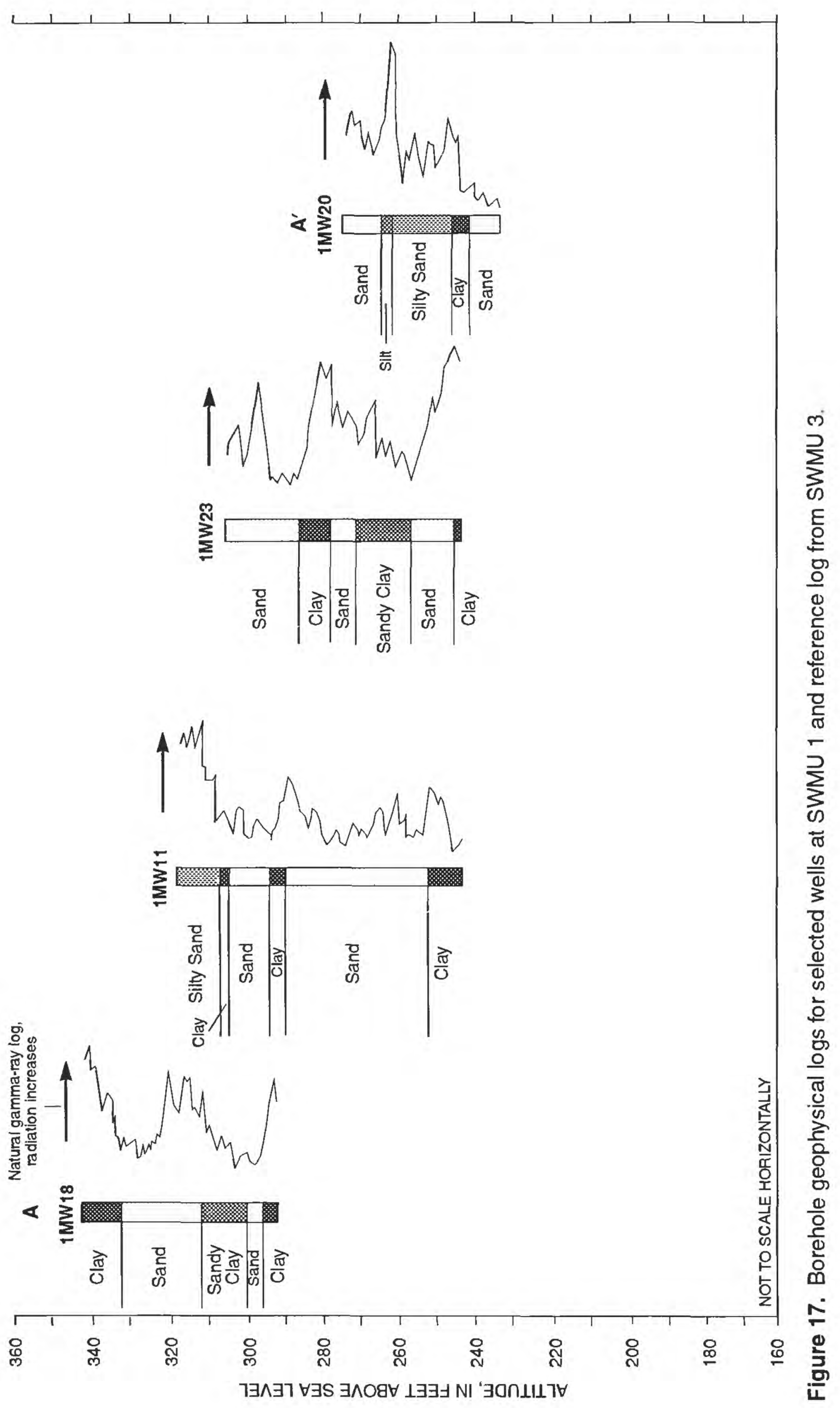

SWMU 129 


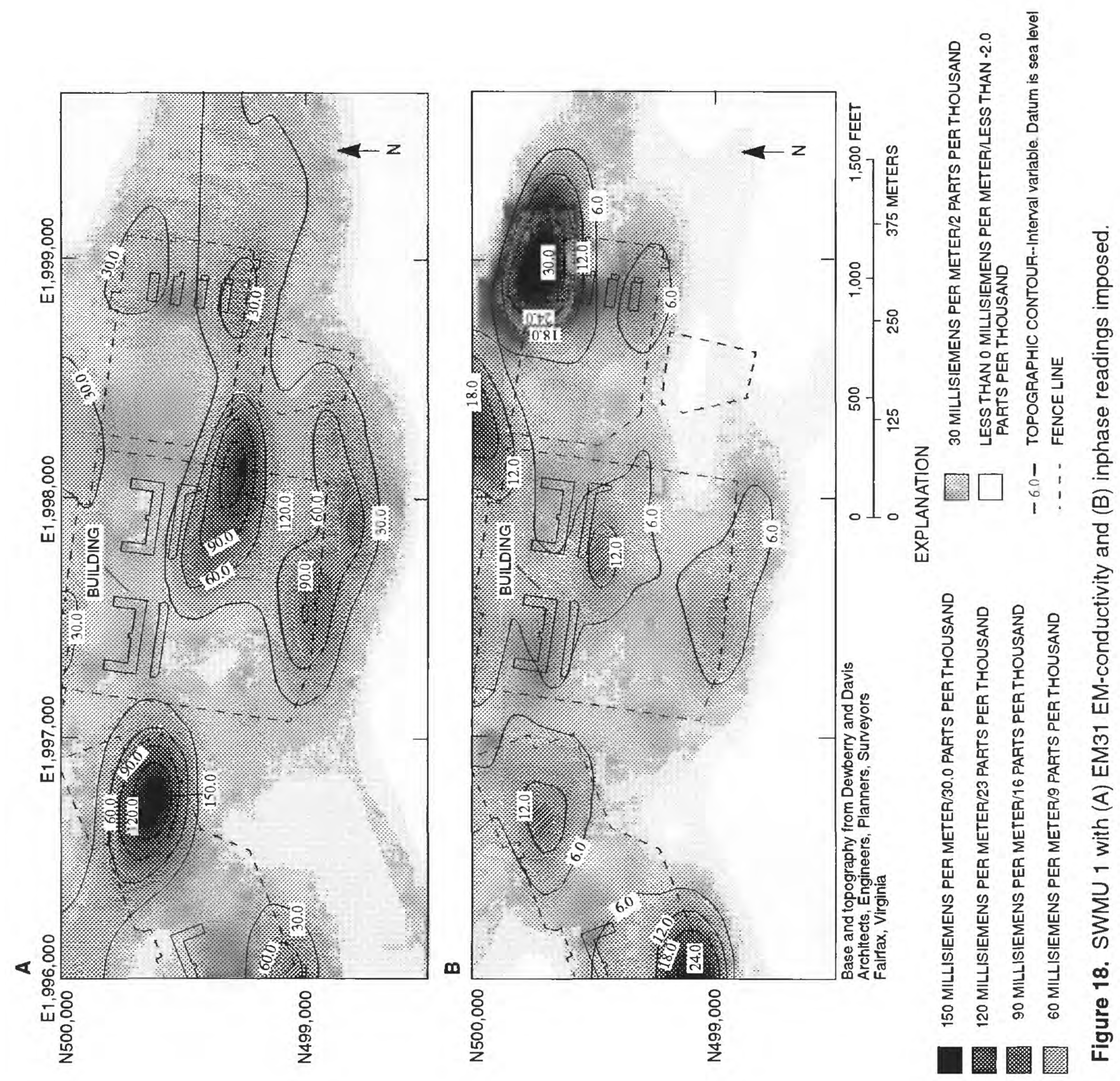


A GPR survey was conducted over the abandoned dumpsite where no test boreholes had been taken. The location of the GPR transects were in the abandoned dumpsite in the vicinity of well $1 \mathrm{MW} 18$ (fig. 16). This area of SWMU 1 contains a paved parking lot and is fairly flat (altitude from 346 to $348 \mathrm{ft})$.

The GPR records show a series of dark, horizontal to angular reflections that gradually lighten and disappear as the GPR signal was gradually attenuated (fig. 19). The deepest interpretable reflections vary from approximately 70 to $150 \mathrm{~ns}$.

A borehole lithologic and geophysical log from well 1MW18 (fig. 17) indicates that thick sand and sandy-clay units underlie a surface clay unit. The interpretable GPR record at this site suggests that the surface clay was stripped away when the dumpsite was in operation and covered with a more sandy material. Thus, the dark reflectors are interpreted as the sandy cover used to backfill the site and the sand unit that occurs between an altitude of approximately 295 and $330 \mathrm{ft}$ at SWMU 1. The gradual lightening of the reflectors is interpreted as an increase in the clay content of the sand and a transition from sandy clay to clay.

The GPR data from all of the survey lines show that the base of the sand unit is irregular with possible interfingering of the base of the sand unit with the top of the underlying sandy-clay to clay unit. Using a dielectric constant of 6 to represent dry sand, the surficial sand unit varies from approximately 10 to $25 \mathrm{ft}$ thick. Lithologic and borehole geophysical logs indicate that this is a reasonable time-to-depth conversion. Some of the abrupt changes in the reflection depths along the survey lines may be due to differential changes in velocities caused by large and abrupt changes in the dielectric constants in the subsurface material. To fully evaluate these potential effects, post-processing techniques such as migration need to be performed.

Several discontinuities occur in many of the reflectors in the top $10 \mathrm{ft}$ of the GPR records 1,4 , and 6 (fig. 19). Buried refuse and debris occur from 2 to $9 \mathrm{ft}$ below land surface in test boreholes in the vicinity of the abandoned dumpsite. Based on these findings, a reasonable interpretation is that these discontinuities represent refuse dispersed throughout the shallow subsurface of the dumpsite.
The data from the geophysical surveys at SWMU 1 demonstrate that the EM31 was useful for delineating the extent of landfill debris (table 3). In addition, 2-D plots of EM-conductivity and inphase data showed anomalies that indicated where landfill refuse is concentrated. The GPR data provided more specific information on the distribution of landfill refuse contained within the EM31 survey anomalies. The GPR data indicated a lateral interfingering of the surficial sand with the underlying clay unit that would be difficult to discern with point-source data, such as lithologic and down-hole geophysical logs obtained from boreholes.

Table 3. Usefulness of EM31 and GPR techniques for hydrogeologic and environmental studies at SWMU 1

[ft, feet]

\begin{tabular}{|c|c|c|}
\hline Technique & Pros & Cons \\
\hline EM31 & $\begin{array}{l}\text { Useful for investigations to } \\
\text { define the areal extent of } \\
\text { landfill material. EM- } \\
\text { conductivity anomalies are } \\
\text { indicative of areas where } \\
\text { landfill debris is } \\
\text { concentrated and where } \\
\text { follow-up GPR surveys } \\
\text { should be conducted. }\end{array}$ & $\begin{array}{l}\text { Provides } \\
\text { limited } \\
\text { depth } \\
\text { information } \\
\text { on } \\
\text { anomalies. }\end{array}$ \\
\hline GPR & $\begin{array}{l}\text { May be useful for } \\
\text { determining the depth and } \\
\text { location of landfill debris } \\
\text { in areas with anomalous } \\
\text { conductivities identified } \\
\text { by the EM31. May provide } \\
\text { more detailed data that can } \\
\text { be used to select } \\
\text { appropriate locations for } \\
\text { test boreholes and well } \\
\text { placement. Effectively } \\
\text { mapped thickness and } \\
\text { lithologic variation of a } \\
\text { surficial sand unit } 10-30 \mathrm{ft} \\
\text { thick and the top of an } \\
\text { underlying clay unit. }\end{array}$ & $\begin{array}{l}\text { Radar-signal } \\
\text { rapidly } \\
\text { attenuated } \\
\text { by clays. } \\
\text { Complex } \\
\text { data may } \\
\text { require post- } \\
\text { processing } \\
\text { with seismic } \\
\text { processing } \\
\text { software. }\end{array}$ \\
\hline
\end{tabular}

\section{Area of Concern (AOC)-F}

AOC-F is located in the northeast corner of the cantonment area (fig. 1). This site was selected for study to assess the utility of electromagnetic conductivity and ground-penetrating radar for the delineation of buried fuel tank that may be of environmental concern. 


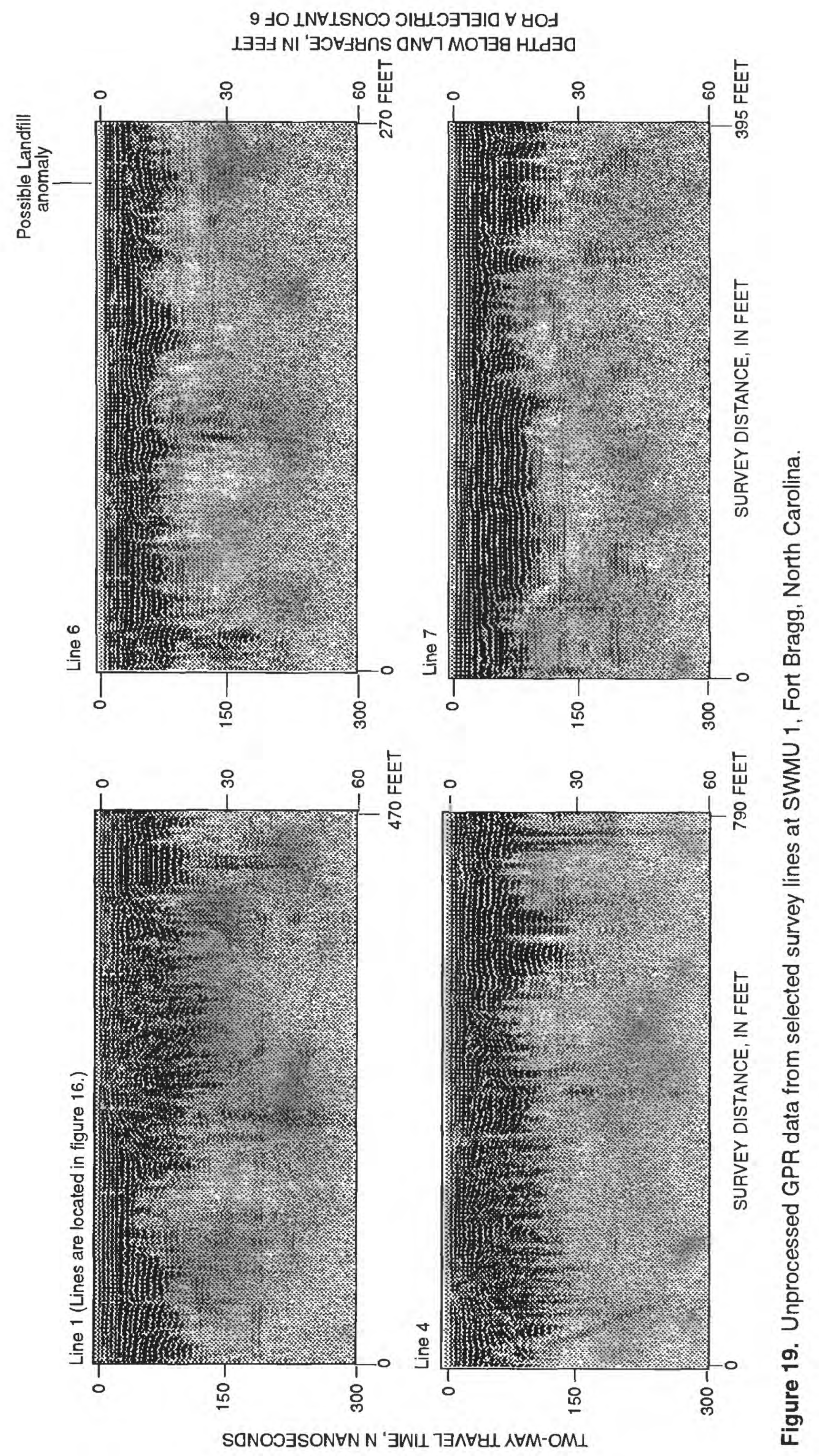




\section{Background}

AOC-F is in a 24 by $50 \mathrm{ft}$ yard-like area behind building 2-7402 (fig. 20). The soil in the yard is sandy. An oily stain about $3 \mathrm{ft}$ in diameter surrounds the fill pipe of an underground fuel-oil tank at this site. The smell of fuel oil is prevalent in the vicinity of the fill pipe. The source of the stain was apparently from a spill during the filling of the tank; however, there also was concern that the tank could be leaking. The close proximity of the fuel-oil tank to buildings and power lines introduced electrical interference. The EM31 and GPR surveys were conducted to assess their usefulness in detecting certain near-surface buried objects of potential environmental concern near such electrical interference. For this study, a 500-MHz shielded antenna was used for the GPR. The small work area and close proximity of the building along with the large coil spacings needed for the EM34 made it impractical to use for this study.

\section{Results and Conclusions}

The EM31-conductivity data show an oblong low just east of line 2 and just west of line 4 (fig. 21A). The size of the anomaly is approximately $3 \mathrm{ft}$ by $12 \mathrm{ft}$. The 2-D plot of the inphase data (fig. 21B) is very similar to the EM-conductivity plot.

The GPR records in figure 22 show that lines 1 through 5 contain a series of broad hyperbolic reflectors that are not present in survey line 6. Hyperbolic reflections are characteristic of when the GPR signal encounters a buried metallic object. The hyperbolic reflections in line 5 are broader and deeper than in lines 1 through 4 indicating that the western edge of the fuel tank is close to line 4. The amplitude of the reflections in lines 1 and 5 are slightly decreased relative to lines 2 through 4 indicating that the eastern edge of the fuel tank is between lines 4 and 5 . The conversion of the twoway travel times to depth, using a dielectric constant for dry sand, shows that the peak of the hyperbolic reflectors is approximately $2 \mathrm{ft}$ below the surface.

The GPR records of lines 1, 3, 5 and 6 also show a strong series of anomalous, small hyperbolic reflections near the right side of the records. This anomaly is most prominent in line 3 . The depth to the top of this anomaly is less than $1 \mathrm{ft}$. The source of this anomaly is not known, but the narrow width of the anomaly indicates that it may be some sort of utility pipe. This anomaly was not picked up by the EM31. If the tank has to be excavated, it is important to know there is some sort of pipe buried close to the fuel tank.
Because the fuel-oil tank was very near the surface, the EM31 and GPR anomalies were essentially the same as the dimensions of the fuel tank. If the tank had been installed deeper below the surface, some modeling and assumptions about the size of the tank would have been necessary to ascertain its actual size. In addition, the deeper the object the more closely spaced the station spacings need to be in order to detect it. Both the EM31 and GPR were useful for defining the location of the buried fuel tank. The data from this survey indicate that the EM31 and GPR are useful methods for detecting and delineating buried tanks, but together provide strong corroborative checks on data interpretation. The detection of a small shallow anomaly, possibly a pipe, also shows that the use of multiple geophysical methods can provide important information that may be missed using just one technique.

\section{DISCUSSION OF RESULTS}

The usefulness of $\mathrm{P}$ - and S-wave shallow seismic-reflection techniques for delineating the subsurface geology at Fort Bragg was evaluated at two background sites. The shallowest reflection event observed on 24-fold CDP stacked P-wave surveys was $70 \mathrm{ft}$ below land surface. Several reflection events between 70 and $120 \mathrm{ft}$ below land surface were associated with the interfaces between alternating sand and clay units in the Cape Fear Formation that were 6 or more feet in thickness (the minimum bed-thickness resolution for $\mathrm{P}$-waves in this area). Deeper reflections occurred at depths of 135 to $140 \mathrm{ft}$ below land surface, close to the interpreted contact of the Cape Fear Formation with the saprolite-basement. The 12-fold CDP stacked P-wave data were more noisy and were sampled less deeply than the 24-fold CDP data. Data from the $S$-wave surveys were plagued by narrow band-width problems associated with the decoupling of the S-wave generator (a sledge hammer and metal plate). The decoupling of the metal plate with the ground narrowed the S-wave band width and created $\mathrm{P}$-waves that interfered with the $\mathrm{S}$-waves. The result was that the 24-fold CDP stacked data contained no coherent reflections. New S-wave generators and geophone arrays have been designed since this study was conducted. Because of the potential enhanced resolution of $\mathrm{S}$-waves relative to $\mathrm{P}$-waves in detecting the subsurface geology in unconsolidated sediments, a new study of S-waves with the updated equipment available could be valuable. 


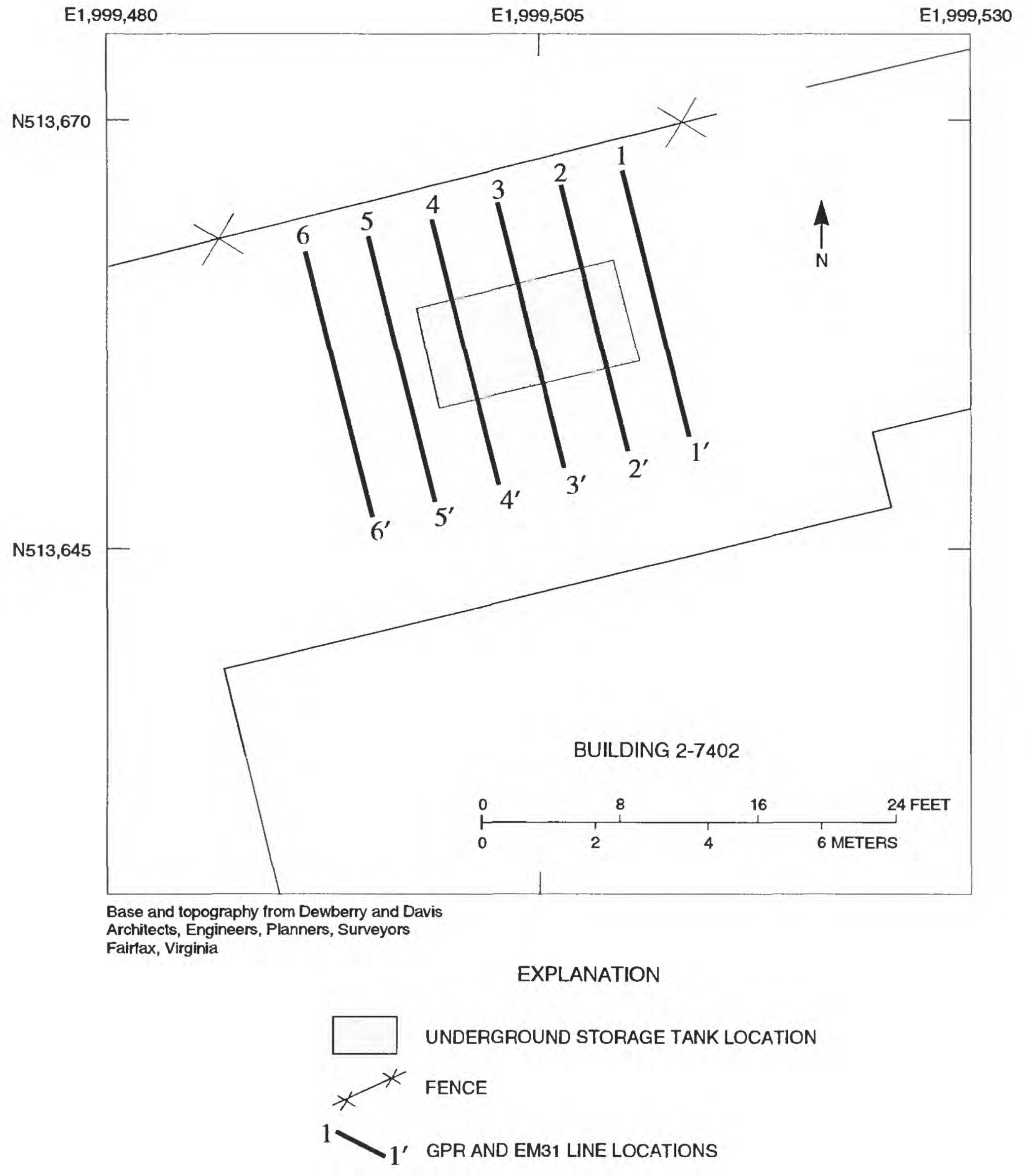

Figure 20. GPR and EM31 lines at AOC-F, Fort Bragg, North Carolina. 

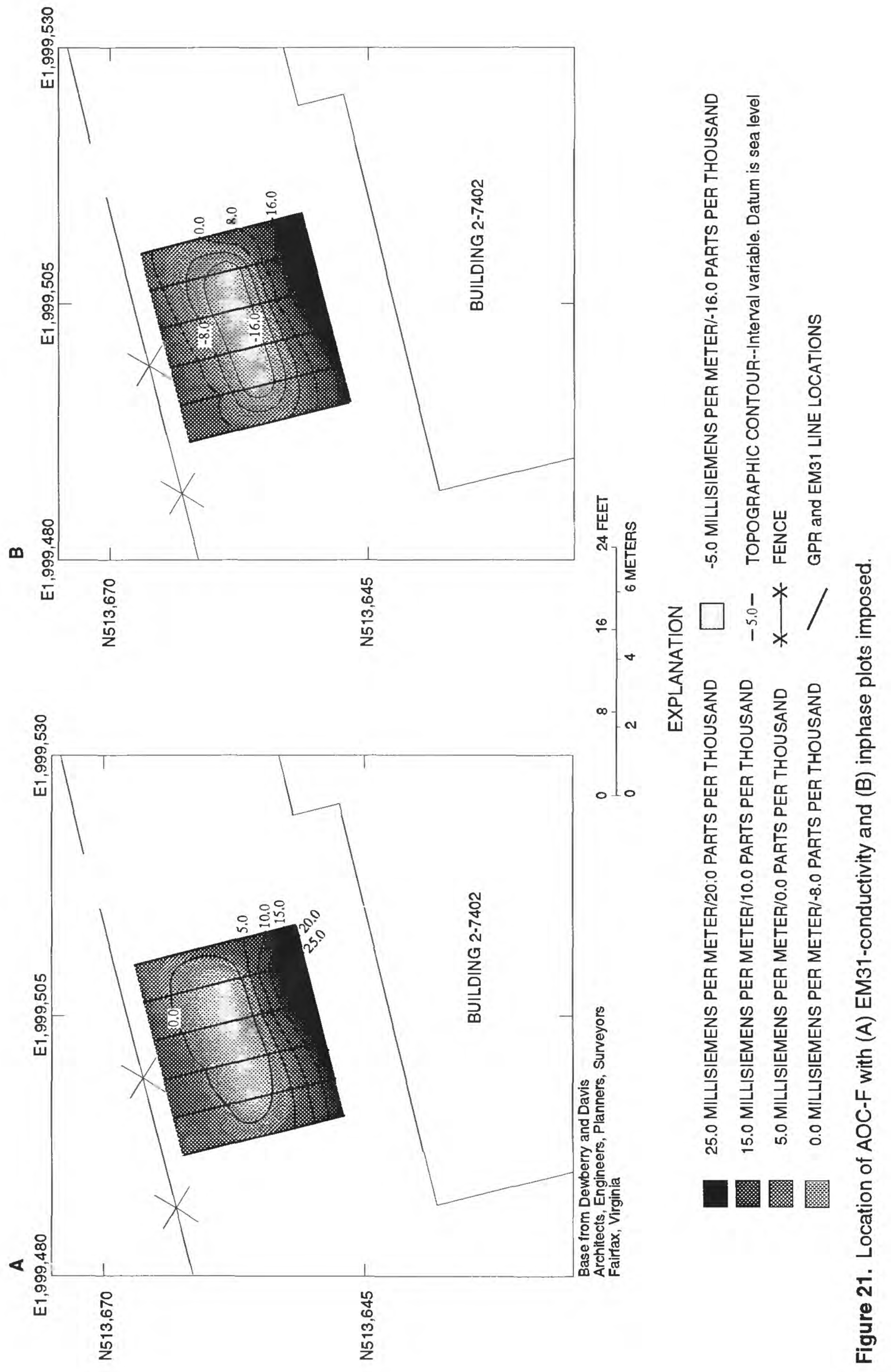


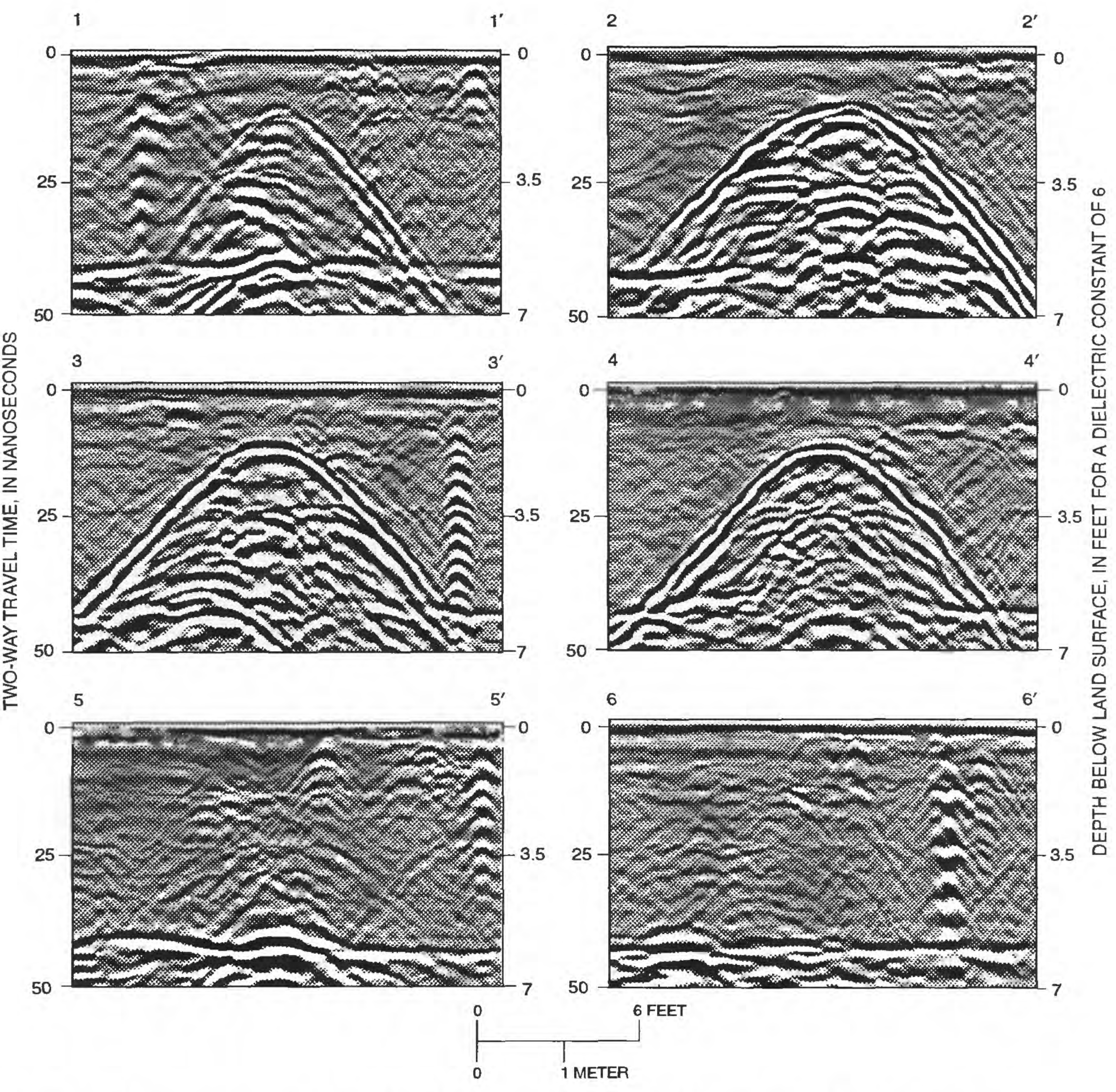

Figure 22. Unprocessed GPR data at AOC-F, collected using 500-MHz antenna. (Line locations are shown in fig. 20.) 
GPR and EM techniques also were evaluated for their ability to map the subsurface geology. A GPR survey at BGS2 effectively mapped a shallow sand unit that dipped and thinned to the northeast. The penetration depth of the radar signal was partially attenuated by a thin clay unit overlying the sand and completely attenuated by another thin clay unit underlying the shallow sand. As the clay units thickened and the sand pinched out to the northeast, the GPR signal was completely attenuated in the very shallow subsurface. The depth of penetration of the GPR signal at this site was less than $10 \mathrm{ft}$ below land surface. Shallow sampling EM-conductivity profiles of data collected by the EM31 and EM34 showed a slight increase in conductivity with increasing thickness of the shallow subsurface clay. These data provided additional evidence that the attenuation of the GPR-signal was due to an increase in the electrical-conductive properties of the subsurface material. However, the EM31 and EM34 data were not directly beneficial in mapping the vertical extent of shallow sand and clay layers. Modeling of the EM34 data using layered-modeling software may provide some insight to the subsurface geology but was beyond the scope of this project. For example, some previous EM31 work performed at Fort Bragg indicated that conductivity varied with the depth of ground water at some sites (S. Howe, U.S. Geological Survey, oral commun., 1996). Thus, there is the potential for some direct applications of terrain conductivity to hydrogeologic studies at Fort Bragg. A summary of the conclusions from the seismic-reflection and electromagnetic techniques for mapping the subsurface geology at Fort Bragg is shown in table 4.

GPR surveys conducted for environmental applications at SWMU 2-14 and SWMU 1 also provided information about the shallow subsurface geology. At these two sites, the GPR effectively mapped the lateral extent of surface sand units that ranged from 5 to $25 \mathrm{ft}$ in thickness and the tops of the clay units that underlay the surficial sand units. The GPR survey data indicate that the usefulness of the GPR for mapping the subsurface geology at Fort Bragg is limited from less than 10 to a maximum of $30 \mathrm{ft}$ below land surface. The exploration depth of the GPR is dependent on the proximity of clay units to the surface.

Combinations of the GPR, EM31, and EM34

were tested at three SWMU's and one AOC to evaluate their ability to assist with environmental studies at Fort Bragg. The GPR was used to delineate the areal extent of a previously unknown extension of SWMU 2-14 under a vehicle salvage yard by mapping the thickness of its landfill cover. The GPR signal was attenuated by the landfill and the adjacent subsurface material making it impossible to differentiate the landfill from the

Table 4. Summary of conclusions for the usefulness of geophysical techniques for mapping the shallow subsurface geology at Fort Bragg, North Carolina

[ft, feet]

\begin{tabular}{|c|c|c|}
\hline Technique & Pros & Cons \\
\hline $\begin{array}{l}\text { P-wave } \\
\text { seismic- } \\
\text { reflection }\end{array}$ & $\begin{array}{l}\text { Useful for mapping continuity of interbedded sand and clay } \\
\text { beds deeper than } 70 \mathrm{ft} \text {, and more than } 6-10 \mathrm{ft} \text { in thickness. } \\
\text { Also useful for mapping the basement surface and the contact } \\
\text { between the Cape Fear Formation and the saprolite-basement. }\end{array}$ & $\begin{array}{l}\text { Not useful for studies that require subsurface } \\
\text { data less than } 50 \text { to } 70 \mathrm{ft} \text { in depth. }\end{array}$ \\
\hline $\begin{array}{l}\text { S-wave } \\
\text { seismic- } \\
\text { reflection }\end{array}$ & $\begin{array}{l}\text { May offer greater resolution than P-waves. New } \mathrm{S} \text {-wave } \\
\text { equipment available to more efficiently generate and collect } \\
\text { S-wave data. }\end{array}$ & $\begin{array}{l}\text { Sledge hammer and plate was an ineffective } \\
\text { S-wave generator. Processed } 24 \text {-fold CDP } \\
\text { data contained no coherent reflections. }\end{array}$ \\
\hline GPR & $\begin{array}{l}\text { Useful for mapping the thickness of surficial sand units. In some } \\
\text { cases, may be useful in detecting transition from sand to clay. }\end{array}$ & $\begin{array}{l}\text { Depth of penetration is dependent on depth and } \\
\text { thickness of shallow subsurface clay units and } \\
\text { the clay content of the sand. Maximum } \\
\text { exploration depth from less than } 10 \mathrm{ft} \text { to } \\
\text { approximately } 30 \mathrm{ft} \text { at Fort Bragg. }\end{array}$ \\
\hline EM31 & $\begin{array}{l}\text { Rapid data collection are easily downloaded and plotted. } \\
\text { Provides corroborative evidence for GPR surveys for } \\
\text { attenuation of radar signal due to subsurface clay layers. }\end{array}$ & $\begin{array}{l}\text { Provides limited information in delineating } \\
\text { between thin sand and clay layers in the } \\
\text { shallow subsurface. }\end{array}$ \\
\hline EM34 & $\begin{array}{l}\text { Fairly rapid data collection. Can collect data for multiple depths. } \\
\text { Can rapidly generate } 2 \text {-D conductivity depth profiles. Layered } \\
\text { modeling programs available. }\end{array}$ & $\begin{array}{l}\text { Provides limited information in delineating } \\
\text { between thin sand and clay layers in the } \\
\text { shallow subsurface. }\end{array}$ \\
\hline
\end{tabular}


surrounding material. The EM31 confirmed that the material underlying the proposed landfill cover, identified by the GPR survey, had different EMconductive properties than the adjacent subsurface material. These data demonstrated that GPR and EM techniques together provided corroborating evidence for the location of the landfill. Local sources of cultural noise at this site (metal fence, parked vehicles, and power lines) showed that the GPR with a shielded antenna was the least affected by cultural noise followed by the EM31 and EM34.

Data from the EM31 and EM34 conductivity surveys at SWMU 5 demonstrated that a landfill boundary was not properly located. The locations of the conductivity anomalies from the EM31 and EM34 were similar. A large EM31 anomaly observed in 2-D interpolated EM-conductivity and inphase plots suggested that landfill material occurred outside of the survey area that was bounded by a metal fence. Data from an EM34 survey, conducted prior to the installation of the fence, confirmed this interpretation. Test boreholes in the vicinity of EM31 and EM34 anomalies indicated that these were areas where landfill debris was concentrated. In addition, the inphase component of the EM31 signal identified areas in the vicinity of test holes where buried metallic debris was found. The result of this study indicate that the EM31 and EM34 are useful for locating landfills by defining the areal extent of landfill debris. In addition, EM-conductivity and inphase anomalies indicate where landfill material is concentrated and where sampling efforts should be concentrated. Construction of 2-D dimensional maps of EM data provides a rapid means to locate anomalies that may define areas of environmental interest.

Anomalies on 2-D plots of EM-conductivity and inphase data from the EM31 were helpful in locating the sites of an old incinerator and an abandoned dumpsite. Landfill debris was found in test boreholes in the vicinity of the EM31 anomalies indicating that the EM31 effectively delineated the extent of landfill and the areas of SWMU 1 where landfill debris was concentrated. A follow-up GPR survey over the abandoned dumpsite, which is now paved, showed discontinuities in the near-surface reflectors that could be landfill debris. Landfill debris was found in test boreholes in wooded areas close to where the GPR survey was conducted. In addition, the depths of reflector breaks are similar to the depths where landfill debris was found in the test borehole. The data from SWMU's 1 and 5 demonstrate that EM 31 is a valid EM-conductivity technique for defining the extent of landfill debris and the areas where it is concentrated. In addition, the GPR is useful for providing more detailed data on the depths and locations of debris in anomalous areas defined by EM surveys.

Finally, the EM31 and GPR also were used to determine the location and depth of a buried fuel-oil tank at AOC-F. Both instruments detected the location and orientation of the buried tank. The GPR survey showed that the tank was buried only a few feet below land surface. The size of the EM31 anomaly confirmed that the tank was close to the surface. The GPR also located a small anomaly, possibly a pipe, adjacent to the tank that was not detected by the EM31. While EM and GPR techniques both provide much useful data for environmental applications at Fort Bragg, the two methods together provide powerful independent corroborative data; one technique may locate something important that the other technique cannot detect. The results of this study reinforce previous findings that multiple surface-geophysical techniques should be used to ensure proper interpretation of data. Table 5 presents a summary of the usefulness of the GPR, EM31 and EM34 for environmental studies at Fort Bragg.

The data from this study indicate that shallow seismic-reflection and GPR surveys have the most promise for their ability to correlate the subsurface geology between stratigraphic test wells at Fort Bragg The minimum resolution depth for shallow seismicreflection surveys is $70 \mathrm{ft}$, and the minimum bed thickness that can be resolved is 6 to $10 \mathrm{ft}$. The GPR was useful in delineating the shallow subsurface geology to a maximum depth of approximately $30 \mathrm{ft}$. The penetration depth of the GPR signal depended on the depth and thickness of the clay layers in the subsurface. The EM31 and EM34 can provide corroborative evidence for lithologic variation in the shallow subsurface detected by GPR. The environmental studies at Fort Bragg show that the EM31 or EM34, with follow-up work by the GPR, provides a significant amount of useful and independent and corroborative data. These data can be used to identify the areal extent and location of landfill material and to plan the locations of test boreholes and monitoring wells. In addition, EM31, EM34 and GPR surveys can be conducted rapidly and the data analyzed immediately to within hours of collection. Local sources of cultural noise, such as metal fences, vehicles, and aircraft, can limit the usefulness of the electromagnetic survey instruments. 
Table 5. Summary of conclusions for the usefulness of geophysical techniques for environmental studies at Fort Bragg, North Carolina [NA, not applicable]

\begin{tabular}{|c|c|c|}
\hline Technique & Pros & Cons \\
\hline GPR & $\begin{array}{l}\text { Useful to define areal extent of landfill cover in areas with considerable sources of } \\
\text { cultural noise. Very useful in conjunction with EM31 surveys to better confirm and } \\
\text { define the location and depth of landfill debris. Useful to identify disturbed areas } \\
\text { where utilities may be buried. Useful for locating buried fuel tanks. }\end{array}$ & $\begin{array}{l}\text { Signal attenuation can make the landfill material } \\
\text { indistinguishable from the adjacent subsurface } \\
\text { material requiring independent confirmation by } \\
\text { terrain conductivity techniques. May not detect } \\
\text { buried utility. }\end{array}$ \\
\hline EM31 & $\begin{array}{l}\text { Useful to distinguish landfill from surrounding sub-surface material. 2-D plots of } \\
\text { EM31 data useful for identifying the areal extent of landfill material and areas } \\
\text { where debris is concentrated. Useful toidentify areas where follow-up GPR surveys } \\
\text { would be most helpful. Inphase component useful for detecting buried pipes. }\end{array}$ & $\begin{array}{l}\text { Need to know dimensions of object to estimate } \\
\text { depth. Limited usefulness in areas with } \\
\text { multiple sources of cultural noise (for example, } \\
\text { metal fences, power lines, vehicles). }\end{array}$ \\
\hline EM34 & $\begin{array}{l}\text { Useful for identifying areal extent of landfill debris. Potentially useful to find deeper } \\
\text { subsurface anomalies than the EM31. }\end{array}$ & Sensitive to sources of cultural noise. \\
\hline $\begin{array}{l}\text { Combination } \\
\text { of techniques }\end{array}$ & $\begin{array}{l}\text { Combinations of GPR and terrain conductivity provides corroborative evidence to } \\
\text { strengthen data interpretation. These studies indicate that more than one surface- } \\
\text { geophysical technique should be used in every study. }\end{array}$ & $\begin{array}{l}\text { More planning, time, and expense using multiple } \\
\text { techniques. }\end{array}$ \\
\hline
\end{tabular}

\section{REFERENCES CITED}

Benson, A.K., 1995, Applications of ground-penetrating radar in assessing some geological hazards: Journal of Applied Geophysics, v. 33, p. 177-193.

Birkelo, B.A., Steeples, D.W., Miller, R.D., and Sophocleous, M.A., 1987, Seismic-reflection study of a shallow aquifer during a pumping test: Ground Water, v. 25, p. 703-709.

Boyce, J.I., Eyles, N., and Pugin, A., 1995, Seismicreflection, borehole, and outcrop geometry of Late Wisconsin Tills at a proposed landfill near Toronto, Ontario: Canadian Journal of Earth Science, v. 32, p. 1331-1349.

Brennan, G.J., 1994, Effectiveness and limitations of electromagnetic surveying, and analysis of the EM34XL: Toledo, Oh., University of Toledo, Masters Thesis, $160 \mathrm{p}$.

Brown, P.M., Miller, J.A., and Swain, F.M., 1972, Structural and stratigraphic framework, and distribution of permeability of the Atlantic Coastal Plain, North Carolina to New York: U.S. Geological Survey WaterResources Investigations Report 89-4195, 33 p.

Brown, P.M., and Parker, J.M., III, 1985, Geologic map of North Carolina: Raleigh, North Carolina Department of Natural Resources and Community Development, Division of Land Resources, Geological Survey Section, scale 1:500,000.
Brus, D.J., Knotters, M., van-Dooremolen, W.A., vanKernebeek, P., and vanSeeters, R.J.M., 1992, The use of electromagnetic measurements of apparent soil electrical conductivity to predict the boulder clay depth: Geoderma, v. 55, p. 79-93.

Conley, J. F., 1962, Geology and mineral resources of Moore County, North Carolina: North Carolina Department of Conservation and Development, Division of Mineral Resources, Bulletin 76, $40 \mathrm{p}$.

Custer, E.S., Jr., 1981, Depositional environments of the subsurface Cretaceous deposits of southeastern North Carolina: Chapel Hill, University of North Carolina at Chapel Hill, Ph.D. dissertation, 116 p.

Daniels, D.L., and Leo, G.W., 1985, Geologic interpretation of basement rocks of the Atlantic Coastal Plain: U.S. Geological Survey Open-File Report 85-655, 43 p., 4 plates.

Daniels, J.J., Roberts, R., and Vendl, M., 1995, Groundpenetrating radar for the detection of liquid contaminants: Journal of Applied Geophysics, v. 33, p. 195-207.

Davis, J.L., Killey, R.W.D., Annan, A.P., and Vaugn, C., 1984, Surface and borehole ground-penetrating radar surveys for mapping geological structures, in Neilson, C.M., and Curl, M., eds., National Water Well Association/EPA conference, San Antonio, Tex., Feb. 7-9, 1984, p. 637-653.

Dobrin, M.B., 1976, Introduction to geophysical prospecting: New York, McGraw-Hill Book Company, $630 \mathrm{p}$. 
Dominic, D.F., Egan, K., Wolfe, P.J., and Boardman, M.R., 1995, Delineation of shallow stratigraphy using groundpenetrating radar: Journal of Applied Geophysics, v. 33, p. $167-175$.

Drane, L.A., III, 1993, Hydrogeology and geophysics of karst terrain in Thompson Township, Seneca County, Ohio, with investigation of the ground-water non-point source pollution from bacteria, nitrates, and pesticides: Toledo, Oh., University of Toledo, Masters Thesis, p. 200.

Hughes, D.R., 1985, Velocity without tears: leading edge of exploration: Society of Exploration Geophysicists, Tulsa, Ok., v. 4, 50 p.

Kearney, Inc., and DPRA, Inc., 1988, Interim facility assessment report, Fort Bragg Military Reservation: U.S. Environmental Protection Agency, Region IV, Contract no. 68-01-7038.

Klimentos, Theodoros., 1995, Attenuation of P- and S-waves as a method of distinguishing gas and condensate from oil and water: Geophysics, v. 60, p. 447-458.

Lieblich, D.A., Haeni, F.P., and Lane, J.W., 1992, Integrated use of surface-geophysical methods to indicate subsurface fractures at Milford, New Hampshire: U.S. Geological Survey Water-Resources Investigations Report 92-4056, 38 p.

McNeil, J.D., 1981, Electromagnetic terrain conductivity measurement at low induction numbers: Geonics Ltd. Technical Note TN-6, 15 p.

Mellett, J.S., 1995, Ground-penetrating radar application in engineering, environmental-management, and geology: Journal of Applied Geophysics, v. 33, p. 157-166.

Miller, R.D., 1992, Normal moveout stretch mute on shallowreflection data: Geophysics, v. 57, p. 1502-1507.

Miller, R.D., Anderson, N.L., Feldman, H.R., and Franseen, E.K., 1995, Vertical resolution of a seismic survey in stratigraphic sequences less than 100 meters deep in southeastern Kansas: Geophysics, v. 60, p. 423-430.

Miller, R.D., Pullan, S.E., Steeples, D.W., and Hunter, J.A., 1994, Field comparison of shallow P-wave seismic sources near Houston, Texas: Geophysics, v. 13, p. 1713-1728.

Miller, R.D., Pullan, S.E., Waldner, J.S., and Haeni, F.P., 1986, Field comparison of shallow seismic sources: Geophysics, v. 59, p. 2067-2092.

Miller, R.D., Steeples, D.W., and Brennan, M., 1989, Mapping bedrock surface under dry alluvium with shallow seismic reflections: Geophysics, v. 54, p. 1528-1534.

Miller, R.D., Xia, Jianghia, Anderson, J.M., and Laflen, D.K., in press, High resolution seismic-reflection surveys at U.S. Marine Corps Air Station, Cherry Point, North Carolina: Lawrence, Kan., Kansas Geological Survey Open-File Report, 95-29.

North Carolina Office of Water Resources, 1980, Groundwater resources of the Southern Pines area, a supplement to the Sandhills capacity-use study: Raleigh, N.C., Department of Natural Resources and Community Development, 41 p.
Olsen, Henrik, and Andreasen, Frank, 1995, Sedimentology and ground-penetrating radar characteristics of a Pleistocene sand deposit: Sedimentary Geology, v. 99, p. 1.

Perry, C.R., 1994, Electromagnetic detection of saltwater in the shallow subsurface along the Saline River Russell County, Kansas: Manhattan, Kans., Kansas State University, Asters Thesis, Masters Thesis, 97 p.

Perry, C.A., Gillespie, J.B., Hargadine, D.A., Gutentag, E.D., and Downey, J.S., 1993, Detection of fractures in Ash Meadows, southwestern Nevada by electromagnetic terrain conductivity measurements: Ground Sensing, v. 1941, p. 113-124.

Salama, R.B., Bartle, G., Farington, P., and Wilson, V., 1994, Basin geomorphological controls on the mechanism of recharge and discharge and its effect on salt storage and mobilization, comparative study using geophysical surveys: Journal of Hydrology, v. 155, p. 1-26.

Smith. D.G., and Jol, H.M., 1995, Ground-penetrating radar -- Antenna frequencies and maximum probable depths of penetration in Quaternary sediments: Journal of Applied Geophysics, v. 33, p. 93-100.

Sohl, F.N., and Owens, J.P., 1991, Cretaceous stratigraphy of the Carolina Coastal Plain, in Horton, J.W., and Zullo, V.A., eds., The Geology of the Carolinas: Knoxville, The University of Tennessee Press, p. 191-220.

Soldal, Oddmund, Mauring, E., Halvorsen, E., and Rye, N., 1994, Seawater intrusion and fresh groundwater hydraulics in fjord delta aquifers inferred from groundpenetrating radar and resistivity profiles: Sunndalsora and Edebotn, Western Norway, Journal of Applied Geophysics, v. 32, p. 305-319.

Steeples, D.W., and Miller, R.D., 1990, Seismic-reflect (RCRA) of (1976) ion methods applied to engineering, environmental, and groundwater problems, in Ward, S.H., ed., Society of Exploration Geophysics Investigations: Geophysics, no. 5, v. 1, Review and Tutoral, p. 1-30.

U.S. Environmental Protection Agency, 1976, Facilities Investigations (RFI) under the Resource Conservation and Recovery Act (RCRA) of (1976): Washington, D.C., Public Law 94-580.

Winn, Rosilee, 1992, Delineation of oil-field brine contamination by electromagnetic-conductivity survey, Midland County, Texas: Odessa, Texas, University of Texas of the Permian Basin, Masters Thesis, p. 78.

Winner, M.D., Jr., and Coble, R.W., 1996, Hydrogeologic framework of the North Carolina Coastal Plain aquifer system: U.S. Geological Survey Professional Paper I404-I, 106 p, 24 plates.

Yilmaz, O., 1987, Seismic data processing, in Doherty, S.M., ed., Society of Exploration Geophysics: Investigations in Geophysics, no. 2, p. 1-30. 